\title{
Whole Genome Sequences Analysis and Homology Modelling of a 3C Like Peptidase and a Non-Structural Protein 3 of the SARS-CoV-2 Shows Protein Ligand Interaction with an Aza-Peptide and a Noncovalent Lead Inhibitor with Possible Antiviral Properties
}

\author{
Arun K. Shanker ${ }^{*}$, Divya Bhanu ${ }^{1,2}$ and Anjani Alluri ${ }^{3}$ \\ ${ }^{1}$ ICAR - Central Research Institute for Dryland Agriculture \\ Santoshnagar, Hyderabad - 500059, India
}

Corresponding author email: arunshank@gmail.com
${ }^{2}$ Centre for Plant Molecular Biology, Osmania University, Hyderabad, India
${ }^{3}$ Advanced Post Graduate Centre, Acharya N.G.Ranga Agricultural University, Guntur, India
Abstract

\begin{abstract}
The family of viruses belonging to Coronaviridae mainly consist of virulent pathogens that have a zoonotic property, Severe Respiratory Syndrome (SARS-CoV) and Middle East Respiratory Syndrome (MERS-CoV) of this family have emerged before and now the SARS-CoV-2 has emerged in China. Characterization of spike glycoproteins, polyproteins and other viral proteins from viruses are important for vaccine development. Homology modelling of these proteins with known templates offers the opportunity to discover ligand binding sites and explore the possible antiviral properties of these protein ligand complexes. Any information emerging from these protein models can be used for vaccine development. In this study we did a complete bioinformatic analysis, sequence alignment, comparison of multiple sequences and homology modelling of the SARS-CoV-2 whole genome sequences, the spike protein and the polyproteins for homology with known proteins, we also analysed receptor binding sites in these models for possible binding with ligands that exhibit antiviral properties. Our results showed that the tertiary structure of the polyprotein isolate SARS-CoV-2_HKU-SZ-001_2020 had 98.94 percent identity with SARSCoronavirus NSP12 bound to NSP7 and NSP8 co-factors. Our results indicate that a part of the viral genome (residues 3268 -3573 in Frame 2 with 306 amino acids) of the SARS-CoV-2 virus isolate Wuhan-Hu-1 (Genbank Accession Number MN908947.3) when modelled with template 2a5i of the PDB database had 96 percent identity with a 3C like peptidase of SARS-CoV which has ability to bind with Aza-Peptide Epoxide (APE) which is known for irreversible inhibition of SARS$\mathrm{CoV}$ main peptidase. The part of the genome (residues 1568-1882 in Frame 2 with 315 amino acids) when modelled with template $3 \mathrm{e} 9 \mathrm{~s}$ of the PDB database had 82 percent identity with a papain-like protease/deubiquitinase which when complexed with ligand GRL0617 acts as inhibitor which can block SARS-CoV replication. It is possible that these viral inhibiters can be used for vaccine development for the SARS-CoV-2.
\end{abstract}

\section{Introduction}

More than a decade has passed since the emergence human Coronavirus that caused Severe Respiratory Syndrome (SARS-CoV) and it is about 7 years since the emergence of another 
34 type of Coronavirus - Middle East Respiratory Syndrome (MERS-CoV) and now the SARS-

35 CoV-2 has emerged in China. This repeated onslaught of these viruses goes to show that it can

36 assume pandemic proportions at any time and at any place.

37 The family of viruses belonging to Coronaviridae mainly consist of virulent pathogens that 38 have a zoonotic property and this large family of corona viruses, have been known to be 39 circulating in animals including camels, cats and bats. It has been seen in the past that Severe 40 Acute Respiratory Syndrome associated coronavirus (SARS-CoV) and Middle East 41 Respiratory Syndrome-associated coronavirus (MERS-CoV) belonging to this family of 42 viruses can be transmitted from animals to humans and can cause respiratory diseases. Human 43 to human transmission on this virus has been a concern and due to this search for antiviral 44 compounds and vaccine development for this family of virus becomes the need of the hour.

45 The SARS was first seen in 2002 in Guangdong province of China, and later spread globally 46 and has caused close to about 8096 cases (WHO 2004, de Vit et al., 2016). In 2012, a novel 47 betacoronavirus, designated Middle East respiratory syndrome coronavirus or MERS-CoV 48 associated with severe respiratory disease in humans, emerged in the Arabian Peninsula (de 49 Wit et al., 2013).

50 The World Health Organization (WHO), China Country Office was informed of cases of 51 pneumonia of unknown aetiology in Wuhan City, Hubei Province, on 31 December 2019 52 (WHO 2020). A novel coronavirus currently termed SARS-COV-2 was officially announced 53 as the causative agent by Chinese authorities on 7 January 2020. As on 20 Feb 2020 China's 54 National Health Commission reported that there are 74,280 confirmed cases in China (Fig.1). 55 The World Health Organization reported 924 confirmed cases in 25 countries outside China 56 (WHO Situation Report 29 2020). This novel corona virus has been designated as SARS-CoV$57 \quad 2$. 
59 Coronaviruses are RNA viruses and have large genomes structures and due to this they can 60 have high error in replication as compared to host genomes. It is also known that various CoVs 61 can do effective recombination of their genomes after infecting host cells (Luo et al 2018). This 62 recombination can be a factor for their evolution to novel types which may have new animals 63 as their intermediate hosts. These factors give the CoVs high adaptive ability and the capability 64 to jump across species and have a relatively large host range.

65 Characterization of Spike glycoproteins from viruses are important for vaccine development. 66 Any information coming from the protein model can be used for vaccine development. In Silico 67 Epitope, polyprotein and spike protein-based peptide vaccine designing for infectious viruses 68 is a way that can hasten the process of vaccine development. Spike (S) protein, polyprotein and 69 other viral proteins of the SARS-CoV-2 as a target for the development of vaccines and 70 therapeutics for the prevention and treatment of infection is an important approach. In the case 71 of SARS-CoV, these proteins can mediate binding of the virus with its receptor and promotes 72 the fusion between the viral and host cell membranes and virus entry into the host cell, hence 73 peptides, antibodies, organic compounds and short interfering RNAs that interact with the spike 74 protein can have a potential role in vaccine development (Du et al 2009).

75 There are multiple domain functions that are active in the replication of the coronavirus and 76 these domains are present in a protein designated as Non-structural protein 3 (nsp3) which is 77 the largest protein in the coronavirus genome (Chen et al 2015). 3C like protease (3CLpro) and 78 Papain like Protease (PLpro) are two important class of proteases that are involved in the 79 process of translation of the polypeptide from the genomic RNA to protein components that 80 are required structurally or non-structurally for replication and packaging of new generation 81 viruses (Liu et al 2020) 
82 We hypothesised that there can be some proteins in the large chuck of proteins in the SARS-

$83 \mathrm{CoV}-2$ that could have homology with the Non-structural protein 3 (nsp3) SARS CoV and

84 these proteins can possibly have binding sites with ligands that can bind with known ligand

85 with antiviral properties.

86 Here in this study we did a complete bioinformatic analysis, sequence alignment, comparison

87 of multiple sequences of the SARS-CoV-2 whole genome sequences, the Spike protein and 88 the polyproteins for homology with known spike proteins and also analysed receptor binding

89 sites for possible vaccine development.

90 Materials and Methods

91 Six complete viral genome sequences, seven polyproteins ( $\mathrm{RdRp}$ region) and seven 92 glycoproteins available on NCBI portal on 4 Feb 2020 were taken for analysis. The sequence

93 details and GenBank accession numbers are listed in Supplementary Table 1. Amongst the 94 seven polyproteins, five are of Wuhan pneumonia virus isolate SARS-COV-2 and two 95 sequences are of Wuhan pneumonia virus isolate SI200040-SP. The seven Glycoproteins are 96 of the same isolate, Wuhan pneumonia virus isolate SARS-COV-2.

97 The available polyproteins (RdRp region) and glycoprotein sequences were retrieved from 98 Genbank, NCBI (Benson et al., 2000). These sequences were translated to amino acid 99 sequences using sorted six frame translation with Bioedit (Hall et al., 2011). Multiple sequence 100 alignment of the translated protein sequences was performed and phylogenetic tree was 101 constructed using Mega-X (Kumar et al., 2018). The alignment shows that amongst the seven 102 polyproteins, five sequences were identical being from the same isolate and two other 103 sequences of the other isolate are identical. Similar analysis of the seven glycoproteins was 104 done, all the seven glycoprotein sequences were found to be identical. Therefore, further 105 analysis was carried out for three sequences. 
106 1. MN938385.1 SARS-CoV-2 virus isolate SARS-COV-2 _HKU-SZ-001_2020 ORF1ab

107 polyprotein, RdRp region, (orflab) gene, partial cds: 0 to 284: Frame 395 aa

108 2. MN970003.1 SARS-CoV-2 virus isolate SI200040-SP orflab polyprotein, RdRP 109 region, (orflab) gene, partial cds: 2 to 289: Frame 296 aa

110 3. MN938387.1 SARS-CoV-2 virus isolate SARS-COV-2 _HKU-SZ-001_2020 surface 111 glycoprotein (S) gene, partial cds: 1 to 105: Frame 135 aa

112 Expasy proteomics server (Gasteiger et al., 2003) was used to study the protein sequence and 113 structural details. These peptides were studied for their physio-chemical properties using the 114 tool Protparam (Gasteiger et al., 2005). The secondary structure analysis was done using Chou 115 and Fasman algorithm with CFSSP (Kumar, 2013). To generate the 3D structure from the fasta 116 sequence, homology modelling was performed and the templates were identified. The model 117 was built using the template with highest identity. Swiss-model (Schwede et al., 2003) was 118 used to build and validate the 3D model, structural assessment was also performed to validate 119 the model built.

120 Complete genome sequence of the SARS-CoV-2 virus isolate Wuhan-Hu-1 (Genbank 121 Accession Number MN908947.3) which has 29903 bp ss-RNA linear was translated sorted 1226 frame with minimum ORF of 20 with any start codon and the resultant protein sequence was 123 used for homology modelling, homology models where done with large chunks of proteins 12421503 to 25381 in Frame 2 with 1293 amino acids, 13450 to 21552 in Frame 1 with 2701 125 amino acids and 254 to 13480 in Frame 2 with 4409 amino acids.

126 SWISS-MODEL server was used for homology modelling (Waterhouse et al 2018) where 127 computation was on ProMod3 engine which is based on Open Structure (Biasini et al 2013). 128 Structural information is extracted from the template, sequence alignment is used to define 129 insertions and deletions. 
130 Protein ligand interaction profile with hydrogen bonding, hydrophobic interactions, salt bridges and $\pi$-Stacking was done with PLIP server (Salentin et al., 2015)

\section{Results and Discussion}

133 The physico- chemical properties and primary structure parameters of the 7 polyproteins RdRp region of the SARS-CoV-2 virus isolate is given in Table 1. RdRP forms an important part of the viral genome where in the RNA viruses its function is to catalyze the synthesis of the RNA strand complementary to a given RNA template.

The isolates SI200040-SP orflab polyprotein and the isolate SI200121-SP orf1ab polyprotein had 2 reading frames as compared to the rest of the isolates which had 3 reading frames. The presence of multiple reading frames suggests the possibility of overlapping genes as seen in many virus and prokaryotes and mitochondrial genomes. This could affect how the proteins are made. The number of amino acid residues in all the polyproteins were the same expect one isolate SI200040-SP which had one amino acid more than the other polyproteins. The extinction coefficients of the two isolates SI200040-SP orflab polyprotein and the isolate SI200121-SP orflab polyprotein was much higher compared to the rest of the polyproteins.

The extinction coefficient is important when studying protein-protein and protein-ligand interactions. The instability index of these two isolates was also high when compared to the others indicating the that these two isolates are instable. Regulation of gene expression by polyprotein processing is known in viruses and this is seen in many viruses that are human pathogens (Yost et al 2013).

The isolates here like many other viruses may be using replication strategy which could involve the translation of a large polyprotein with subsequent cleavage by viral proteases. The two 152 isolates SI200040-SP orflab polyprotein and the isolate SI200121-SP orf1ab polyprotein also showed shorter half-lives as compared to the other isolates indicating that they are susceptible to enzymatic degradation. 
155 The tertiary structure analysis of the isolate SARS-CoV-2 _HKU-SZ-001_2020 ORF1ab 156 polyprotein is given in Table 2. It is seen that the polyprotein has a 98.94 percent identity with

157 PDB structure 6nur.1.A which is a hetero-1-2-1-mer. The polyprotein is an RNA directed RNA 158 polymerase. The protein is identical to the SARS-Coronavirus NSP12 bound to NSP7 and 159 NSP8 co-factors (Kirchdoerfer and Ward 2019). In SARS it is basically a nonstructural protein 160 with NSP12 being the RNA dependent RNA polymerase and the co factors NSP 7 and NSP 8 161 having the function of forming hexadecameric complexes and also act as processivity clamp 162 for RNA polymerase and primase (Fehr et al., 2016). This structure as in SARS CoV here in 163 SARS-CoV-2 may be involved in the machinery of core RNA synthesis and can be a template 164 for exploring antiviral properties.

165 The phylogenetic tree of the seven polyproteins is shown in Fig.2. It is seen that two 166 polyproteins were distinctly different from the rest. The Phylogenetic tree of the seven 167 glycoproteins of the SARS-CoV-2 virus isolate is shown in Fig.3, it is seen that the 168 glycoproteins are similar in all the isolates. Multiple alignment of the Polyproteins of the 169 SARS-CoV-2 is shown in Supplementary Fig.1.

170 This structure as in SARS CoV here in SARS-CoV-2 may be involved in the machinery of core 171 RNA synthesis and can be a template for exploring antiviral properties. Based on its functions 172 in the SARS CoV and its identity to the SARS-CoV-2, it is possible that it has the same 173 functions in SARS-CoV-2 an RNA polymerase which does de novo initiation and primer 174 extension with possible exonuclease activities, the activity itself being primer dependent useful 175 for understanding the mechanism of SARS-CoV-2 replication and can be used as an antiviral 176 target (Te Velthuis et al 2012; Te Velthuis et al 2010; Subissi et al 2014; Subissi et al 2014). 
178 The polyprotein also has an identity of 19.74 percent with an ABC-type uncharacterized 179 transport system periplasmic component-like protein, this protein is known to be a substrate 180 binding protein and possible binding can be explored here (Bae et al 2019).

181 The homology model developed from the residues 254 to 13480 in Frame 2 with 4409 amino 182 acids from the Complete genome sequence of the SARS-CoV-2 virus isolate Wuhan-Hu-1 183 (Genbank Accession Number MN908947.3) which has 29903 bp with linear ss-RNA linear 184 showed interesting template alignments, in all the model aligned with 50 templates from the 185 PDB database with most of them being replicase polyprotein $1 \mathrm{ab}$ which is a SARS-CoV 186 papain-like protease (Daczkowski 2017). The maximum similarity of 97.3 percent was with 187 template structure of a Nsp9 protein from SARS-coronavirus indicating that this novel 188 coronavirus has high degree of similarity with the SARS-coronavirus and this can be used for 189 gaining insights into vaccine development. Nsp 9 is an RNA binding protein and has an 190 oligosaccharide/oligonucleotide fold-like fold, this protein can have an important function in 191 the replication machinery of the virus and can be important when designing antiviral for this 192 virus (Egloff et al 2004).

193 Two models were developed, one from residues $3268-3573$ in Frame 2 with 306 amino 194 acids and the other from the part of the genome residues 1568-1882 in Frame 2 with 315 amino acids of the SARS-CoV-2 virus isolate Wuhan-Hu-1 (Genbank Accession Number MN908947.3). The models had similarity with the 3C like proteinase and a papain-like 197 protease/deubiquitinase protein which are known antiviral drug targets. Ligand binding with 198 these proteins and their action is on viral replication and inactivation can be useful in stopping 199 the viral replication (Baez-Santos et al 2015). 
201 The homology models of the 4409 amino acid residues of the whole genome of the SARS-

$202 \mathrm{CoV}-2$ virus isolate Wuhan-Hu-1 with the ligand association with templates $2 \mathrm{a} 5 \mathrm{i}$ and $3 \mathrm{e} 9 \mathrm{~s}$ are 203 shown in Fig. 4 and Fig. 5 respectively.

204 The statistics of structural comparison with PDB templates is given in Table 5, it is seen that 205 the proteins from the SARS-CoV-2 are significantly close to the proteins of SARS CoV and 206 the amino acid alignment in the biding region is the same in both the viruses.

207 The alignment of the 305 residues from 3268-3573 aa of the Novel Coronavirus COVI-19 with 208 the template $2 \mathrm{a} 5 \mathrm{i}$ is shown in Fig. 6 and the alignment of the 315 residues from $1568-1882$ aa 209 of the Novel Coronavirus COVI-19 with the template 3e9s is shown in Fig.7.

210 The important templates that aligned with this 4409 amino acid residues of the whole genome 211 of the SARS-CoV-2 virus isolate Wuhan-Hu-1were 2a5i of the PDB database which is a 212 crystal structure of SARS coronavirus main peptidase inhibited by an Aza-Peptide epoxide in 213 the space group C2 (Lee et al 2005) and 3e9s of the PDB database which is new class of 214 papain-like protease/deubiquitinase which when combined with ligand GRL0617 acts as 215 inhibitors blocking SARS virus replication (Ratia et al 2008). The model with template 2a5i of 216 the PDB database shows that Aza-Peptide Epoxide (APE; kinact/Ki=1900( \pm 400$) \mathrm{M}^{-1} \mathrm{~s}^{-1}$ ) 217 which is a known anti SARS agent can be used to develop a molecular target with irreversible 218 inhibitor properties. The protein ligand interaction analysis of the Novel Coronavirus C3 like 219 peptidase and aza-peptide epoxide is shown in Fig.8. The substrate binding properties and 220 structural and chemical complementarity of this Aza-Peptide Epoxide can be explored as an 221 anti - Coronavirus SARS-COV-2 agent. The APE which is ethyl (2S)-4-[(3-amino-3-oxo222 propyl)-[[(2S)-2-[[(2S)-4-methyl-2-phenylmethoxycarbonylamino-pentanoyl]amino]-3phenyl-propanoyl]amino]amino]-2-hydroxy-4-oxo-butanoate structure is shown in Fig.9. 
225 The model with template $3 \mathrm{e} 9 \mathrm{~s}$ of the PDB database shows that the Coronavirus viral protein

226 can have a ligand which is a papain-like protease (PLpro) that is known to be a potent inhibitor

227 of viral replication in SARS (Ratia et al 2008).

228 The two parts of the Main protein from the whole genome of the SARS-CoV-2 aligned with 229 two SAR proteins and the ligand binding sites were similar, the alignment positions, number 230 of amino acids and ligand and the interacting residues is given in Table 3

231 The complete genome of MN908947.3 SARS-CoV-2 virus isolate Wuhan-Hu-1 encodes a 232 4409aa long protein along with the other glycoproteins and polyproteins. The homology 233 modelling of this protein showed sequence and structural alignment with two SARS proteases 234 with structural accession numbers 3e9s.1 and 2a5i.1 at positions 1568-1882 and 3268-3573 respectively. Reports suggests inhibition of virus replication by TTT ligand and an aza-peptide epoxide inhibiting the main peptidase. The structural similarity of these templates are $83 \%$ and $23796 \%$ respectively. The multiple sequence alignment shows complete conservation of the sequence suggesting a high degree of homology. The protein ligand interaction analysis of the Novel Coronavirus non structural protein and papain-like protease is shown in Fig. 10.

240 The Comparison of Hydrophobic interaction, hydrogen bonding, salt bridges of the constructed model of the Novel Coronavirus protein from region 3268-3573 aa to ligand AZP with Hydrophobic interaction, hydrogen bonding, salt bridges of the template $2 \mathrm{a} 5 \mathrm{i}$ is given in Suppl. Table 2, when comparing both it is seen that the binding properties are the same expect 244 for the presence of water bridge in the template $2 \mathrm{a} 5 \mathrm{i}$.

246 The Comparison of Hydrophobic interaction, hydrogen bonding, $\pi$-Stacking of the constructed 247 model of the Novel Coronavirus protein from region 1568-1882 aa to ligand Small molecule 248 Noncovalent Lead Inhibitor with the Hydrophobic interaction, hydrogen bonding, $\pi$-Stacking 
of the template $3 \mathrm{e} 9 \mathrm{~s}$ is given in Suppl. Table 3, when comparing both it is seen that the binding properties are the same except or an additional $\pi$-Stacking at Tyr in the template $2 \mathrm{a} 5 \mathrm{i}$. This shows that there is high possibility of binding of these antiviral compounds with the regions of Novel Coronavirus protein that is in homology with the SARS protein.

Comparison of the hydrophobic interaction of the biding of the ligand AZP between the SARSCoV-2 protein and the template $2 \mathrm{a} 5 \mathrm{i}$ of SARS CoV is shown in Fig. 11 and the comparison of the hydrophobic interaction of the biding of the ligand AZP between the SARS-CoV-2 protein and the template $3 \mathrm{e} 9 \mathrm{~s}$ of SARS CoV is shown in Fig.12. It is seen that the interaction is the same in both proteins with the same amino acids participating in the interaction indicating that there is a possibility that these ligands with antiviral properties can bind to the new virus.

The similarity in the amin acids involved in the Hydrophobic interactions which are short range interactions and have an important role in the affinities of the ligands and receptors shows that the proteins of the SARS-CoV-2 may bind with the same affinity as seen in the SARS CoV and this also shows a similar action of the ligand as seen in SARS CoV, indicating that these ligands can be used as antivirals in the SARS-CoV-2.

The targeting of this part of the genome of the SARS-CoV-2 with the antiviral compounds which have shown to bind in the similar region of the SARS virus can have implication in the development of an effective antiviral compound against the SARS-CoV-2 . The SARS-CoV-2 shows homology with the SARS coronaviral proteases, papain-like protease (PLpro) and 3Clike protease (3CLpro), these proteins have the function of processing the viral polyprotein and also they perform the function of stripping ubiquitin and the ubiquitin-like interferon (IFN)stimulated gene 15 (ISG15) from the hosts to facilitate coronavirus replication and help in evading immune response of the host, these inhibitors can also have a role in disrupting signalling cascades in infected cells and protecting the uninfected cells. 
273 The chemical GRL0617 is 5-Amino-2-methyl-N-[(1R)-1-(1-naphthalenyl)ethyl]benzamide 274 and is known to inhibit the papainlike protease that is present in SARS CoV . This protease is 275 a potential target for antiviral compounds (Chaudhuri et al., 2011). We found the SARS-CoV-

2762 has homology with this and the binding sites for this in the structural protein of the SARS-

$277 \mathrm{CoV}-2$ is the same (Table 4). This compound inhibits the enzyme that is required for the 278 cleavage of the viral protein from the virus in SARS CoV, it also cleaves ubiquitin and has a 279 structural homology with the Deubiquitinases (DUBs) of the Ubiquitin-Specific Proteases 280 Compound GRL0617 binds in the S4 and S3 enzyme subsite that gets the C terminal tail of the 281 Ubiquitin (King and Finley 2014; Schauer et al., 2019). Our results show that Aza-Peptide 282 Epoxide an irreversible protease inhibitor and GRL0617 a viral replication inhibitor can be 283 used to develop inhibitors of the Novel Coronavirus SARS-COV-2.

\section{References}

Bae, J.E., Kim, I.J., Kim, K.J. and Nam, K.H., 2018. Crystal structure of a substrate-binding protein from Rhodothermus marinus reveals a single $\alpha / \beta$-domain. Biochemical and (2000). GenBank. Nucleic Acids Rresearch, 28(1), 15-18. Biophysical Research Communications, 497(1), pp.368-373.

Baez-Santos, Y.M., John, S.E.S. and Mesecar, A.D., 2015. The SARS-coronavirus papain-like protease: structure, function and inhibition by designed antiviral compounds. Antiviral Research, 115, pp.21-38.

Benson, D. A., Karsch-Mizrachi, I., Lipman, D. J., Ostell, J., Rapp, B. A., \& Wheeler, D. L.

Biasini, M., Schmidt, T., Bienert, S., Mariani, V., Studer, G., Haas, J., Johner, N., Schenk, 295 A.D., Philippsen, A. and Schwede, T., 2013. OpenStructure: an integrated software 
framework for computational structural biology. Acta Crystallographica Section D: Biological Crystallography, 69(5), pp.701-709.

Chaudhuri, R., Tang, S., Zhao, G., Lu, H., Case, D.A. and Johnson, M.E., 2011. Comparison of SARS and NL63 papain-like protease binding sites and binding site dynamics: inhibitor design implications. Journal of molecular biology, 414(2), pp.272-288.

Chen, Y., Savinov, S.N., Mielech, A.M., Cao, T., Baker, S.C. and Mesecar, A.D., 2015. X-ray structural and functional studies of the three tandemly linked domains of non-structural protein 3 (nsp3) from murine hepatitis virus reveal conserved functions. Journal of Biological Chemistry, 290(42), pp.25293-25306.

Daczkowski, C.M., Dzimianski, J.V., Clasman, J.R., Goodwin, O., Mesecar, A.D. and Pegan, S.D., 2017. Structural insights into the interaction of coronavirus papain-like proteases and interferon-stimulated gene product 15 from different species. Journal of Molecular Biology, 429(11), pp.1661-1683.

de Wit, E., Rasmussen, A.L., Falzarano, D., Bushmaker, T., Feldmann, F., Brining, D.L., Fischer, E.R., Martellaro, C., Okumura, A., Chang, J. and Scott, D., 2013. Middle East respiratory syndrome coronavirus (MERS-CoV) causes transient lower respiratory tract infection in rhesus macaques. Proceedings of the National Academy of Sciences, 110(41), pp.16598-16603.

de Wit, E., van Doremalen N., D. Falzarano, V. J. Munster, SARS and MERS: recent insights into emerging coronaviruses. Nat Rev Microbiol 14, 523-534 (2016).

Du, L., He, Y., Zhou, Y., Liu, S., Zheng, B.J. and Jiang, S., 2009. The spike protein of SARS$\mathrm{CoV}-\mathrm{a}$ target for vaccine and therapeutic development. Nature Reviews Microbiology, 7(3), pp.226-236. 
Egloff, M.P., Ferron, F., Campanacci, V., Longhi, S., Rancurel, C., Dutartre, H., Snijder, E.J., Gorbalenya, A.E., Cambillau, C. and Canard, B., 2004. The severe acute respiratory syndrome-coronavirus replicative protein nsp9 is a single-stranded RNA-binding subunit unique in the RNA virus world. Proceedings of the National Academy of Sciences, 101(11), pp.3792-3796.

Fehr, A.R. and Perlman, S., 2015. Coronaviruses: an overview of their replication and pathogenesis. In Coronaviruses (pp. 1-23). Humana Press, New York, NY.

Gasteiger, E., Gattiker, A., Hoogland, C., Ivanyi, I., Appel, R. D., \& Bairoch, A. (2003). ExPASy: the proteomics server for in-depth protein knowledge and analysis. Nucleic Acids Research, 31(13), 3784-3788.

Gasteiger, E., Hoogland, C., Gattiker, A., Wilkins, M. R., Appel, R. D., \& Bairoch, A. (2005). Protein identification and analysis tools on the ExPASy server. In The proteomics protocols handbook (pp. 571-607). Humana press.

Hall, T., Biosciences, I., \& Carlsbad, C. (2011). BioEdit: an important software for molecular biology. GERF Bull Biosci, 2(1), 60-61.

King, R.W. and Finley, D., 2014. Sculpting the proteome with small molecules. Nature chemical biology, 10(11), p.870.

Kirchdoerfer, R.N. and Ward, A.B., 2019. Structure of the SARS-CoV nsp12 polymerase bound to nsp7 and nsp8 co-factors. Nature Communications, 10(1), pp.1-9.

Kumar, S., Stecher, G., Li, M., Knyaz, C., \& Tamura, K. (2018). MEGA X: molecular evolutionary genetics analysis across computing platforms. Molecular Biology and Evolution, 35(6), 1547-1549. 
Kumar, T. A. (2013). CFSSP: Chou and Fasman secondary structure prediction server. Wide Spectrum, 1(9), 15-19.

Lee, T.W., Cherney, M.M., Huitema, C., Liu, J., James, K.E., Powers, J.C., Eltis, L.D. and James, M.N., 2005. Crystal structures of the main peptidase from the SARS coronavirus inhibited by a substrate-like aza-peptide epoxide. Journal of Molecular Biology, 353(5), pp.1137-1151.

Liu, W., Morse, J.S., Lalonde, T. and Xu, S., 2020. Learning from the Past: Possible Urgent Prevention and Treatment Options for Severe Acute Respiratory Infections Caused by 2019-nCoV. ChemBioChem.

Luo, C.M., Wang, N., Yang, X.L., Liu, H.Z., Zhang, W., Li, B., Hu, B., Peng, C., Geng, Q.B., Zhu, G.J. and Li, F., 2018. Discovery of novel bat coronaviruses in south China that use the same receptor as Middle East respiratory syndrome coronavirus. Journal of Virology, 92(13), pp.e00116-18.

Ratia, K., Pegan, S., Takayama, J., Sleeman K., Coughlin, M., Baliji, S., Chaudhuri, R., Fu, W., Prabhakar, B.S., Johnson, M.E. and Baker, S.C., 2008. A noncovalent class of papain-like protease/deubiquitinase inhibitors blocks SARS virus replication. Proceedings of the National Academy of Sciences, 105(42), pp.16119-16124.

Salentin, S., Schreiber, S., Haupt, V.J., Adasme, M.F. and Schroeder, M., 2015. PLIP: fully automated protein-ligand interaction profiler. Nucleic acids research, 43(W1), pp.W443-W447

Schauer, N.J., Magin, R.S., Liu, X., Doherty, L.M. and Buhrlage, S.J., 2019. Advances in Discovering Deubiquitinating Enzyme (DUB) Inhibitors. Journal of medicinal chemistry. 
Schwede, T., Kopp, J., Guex, N., \& Peitsch, M. C. (2003). SWISS-MODEL: an automated protein homology-modeling server. Nucleic Acids Research, 31(13), 3381-3385.

Subissi, L., Imbert, I., Ferron, F., Collet, A., Coutard, B., Decroly, E. and Canard, B., 2014. SARS-CoV ORF1b-encoded nonstructural proteins 12-16: replicative enzymes as antiviral targets. Antiviral research, 101, pp.122-130.

Subissi, L., Posthuma, C.C., Collet, A., Zevenhoven-Dobbe, J.C., Gorbalenya, A.E., Decroly, E., Snijder, E.J., Canard, B. and Imbert, I., 2014. One severe acute respiratory syndrome coronavirus protein complex integrates processive RNA polymerase and exonuclease activities. Proceedings of the National Academy of Sciences, 111(37), pp.E3900E3909.

Te Velthuis, A.J., Arnold, J.J., Cameron, C.E., van den Worm, S.H. and Snijder, E.J., 2010. The RNA polymerase activity of SARS-coronavirus nsp12 is primer dependent. Nucleic acids research, 38(1), pp.203-214.

Te Velthuis, A.J., van den Worm, S.H. and Snijder, E.J., 2012. The SARS-coronavirus nsp7+ nsp8 complex is a unique multimeric RNA polymerase capable of both de novo initiation and primer extension. Nucleic acids research, 40(4), pp.1737-1747.

Waterhouse, A., Bertoni, M., Bienert, S., Studer, G., Tauriello, G., Gumienny, R., Heer, F.T., de Beer, T.A.P., Rempfer, C., Bordoli, L. and Lepore, R., 2018. SWISS-MODEL: homology modelling of protein structures and complexes. Nucleic Acids Research, 46(W1), pp.W296-W303.

World Health Organization (WHO) 2004. [Accessed 11 Feb 2020] https://www.who.int/csr/don/2004_05_18a/en/ 
World Health Organization (WHO). Coronavirus. Geneva: WHO; 2020 [Accessed 4 Feb 2020]. Available from: https://www.who.int/health-topics/coronavirus

Yost, S.A. and Marcotrigiano, J., 2013. Viral precursor polyproteins: keys of regulation from replication to maturation. Current Opinion in Virology, 3(2), pp.137-142.

\section{Figure Captions}

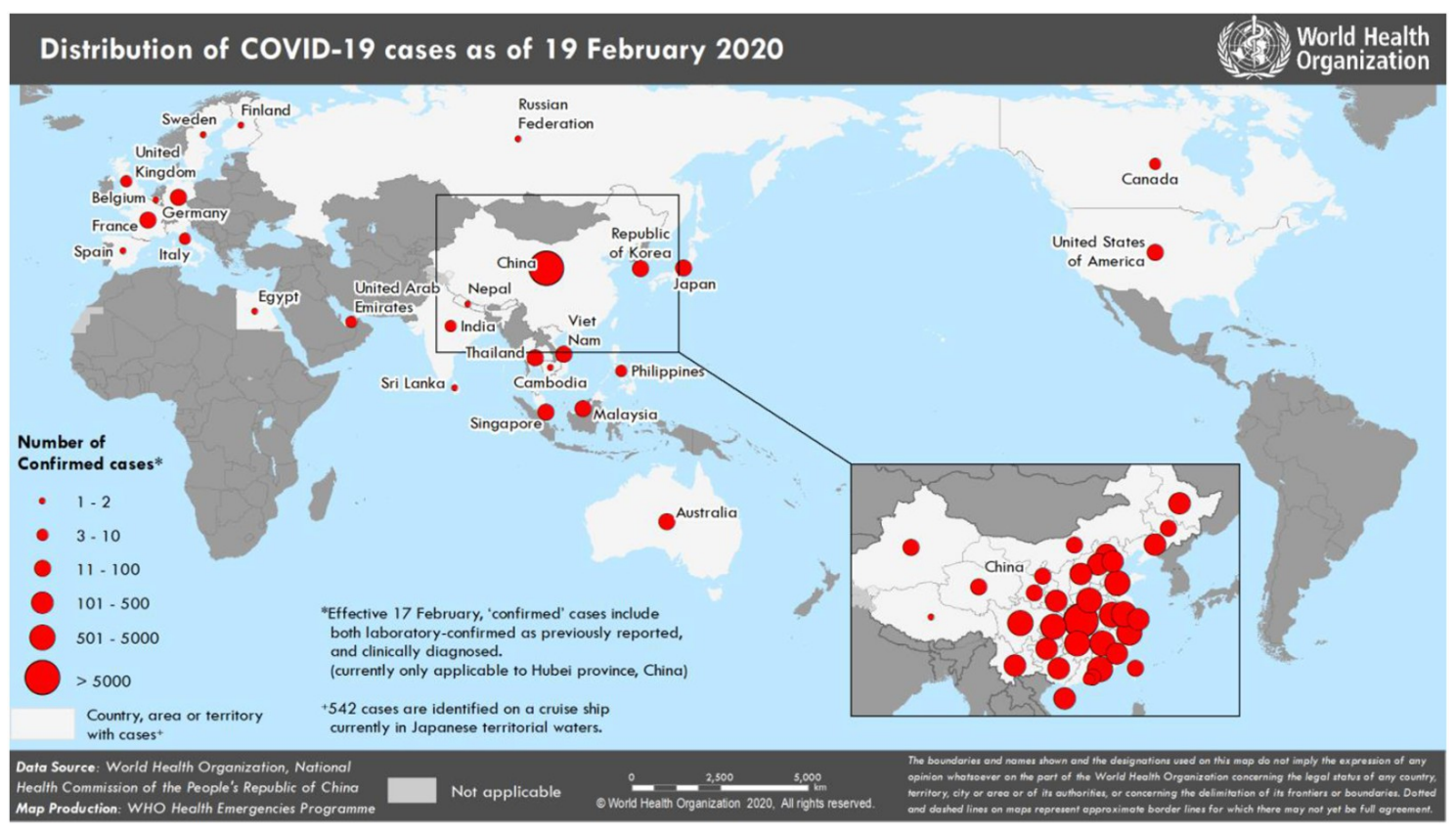

Fig.1 Countries, territories or areas with reported confirmed cases of SARS-COV-2 , 3 $\begin{array}{llll}\text { February } & 2020 & \text { Source } & \text { WHO }\end{array}$ (https://www.who.int/docs/defaultource/coronaviruse/situation-reports/20200219-sitrep-30-covid19.pdf?sfvrsn=6e50645_2) 


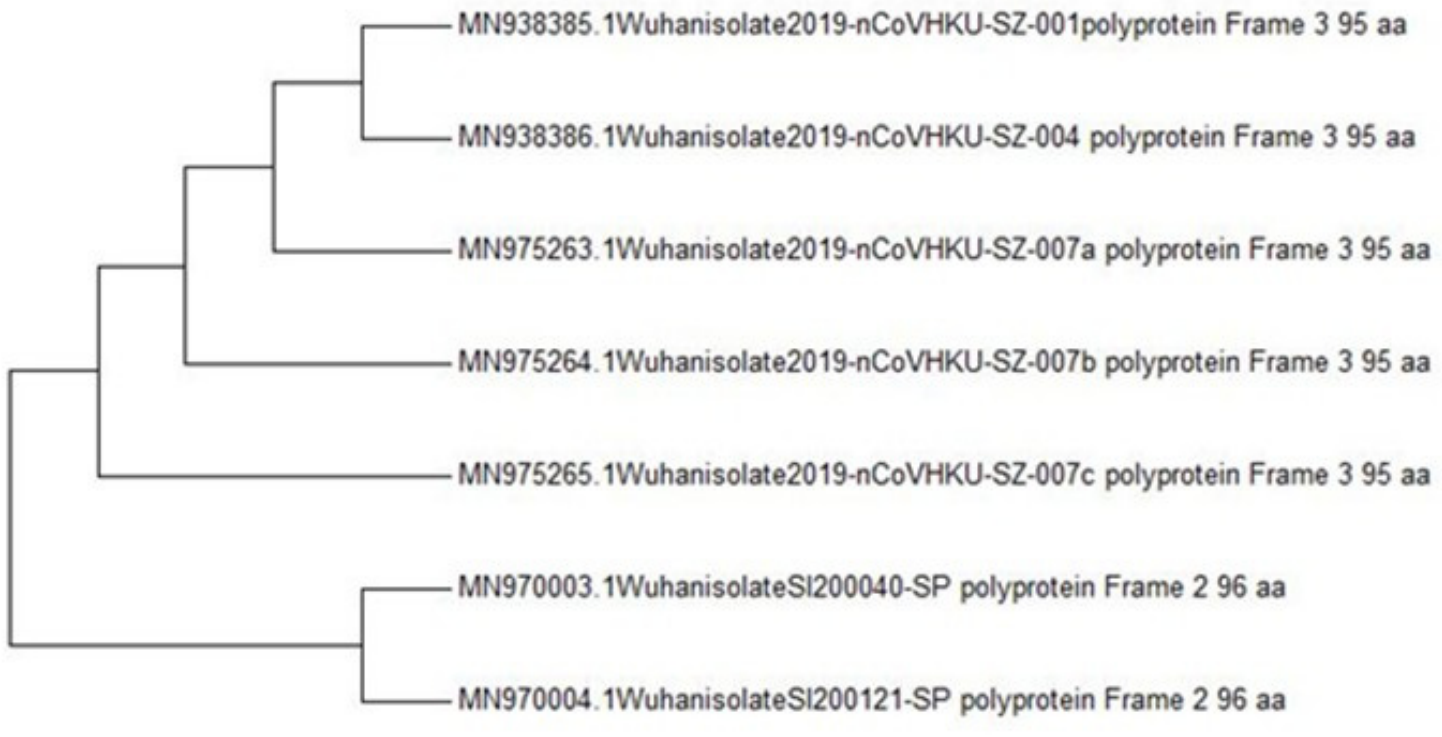

Fig.2 Phylogenetic tree of the seven polyproteins of Severe acute respiratory syndrome 399 coronavirus 2 isolate virus isolates

400

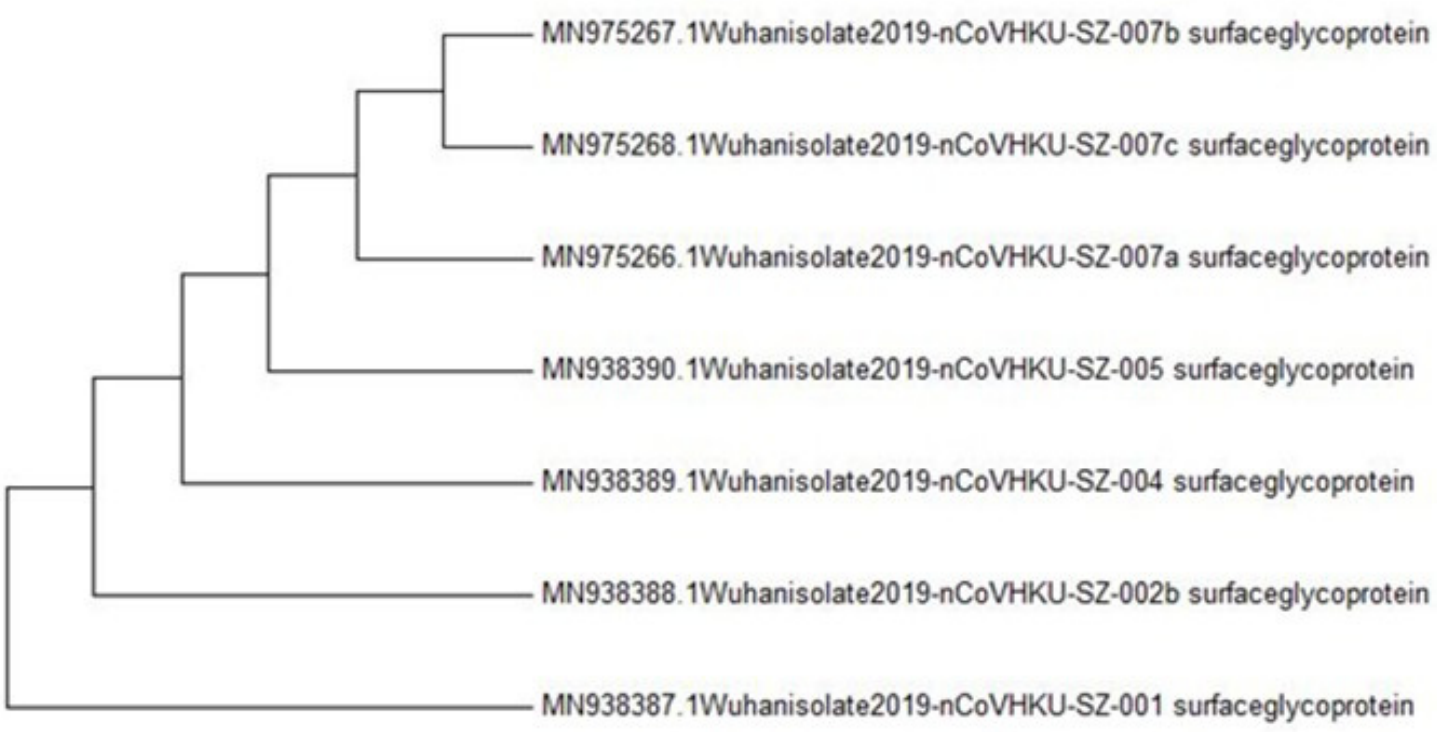

401 Fig.3 Phylogenetic tree of the seven glycoproteins of Severe acute respiratory syndrome 402 coronavirus 2 isolate virus isolates 


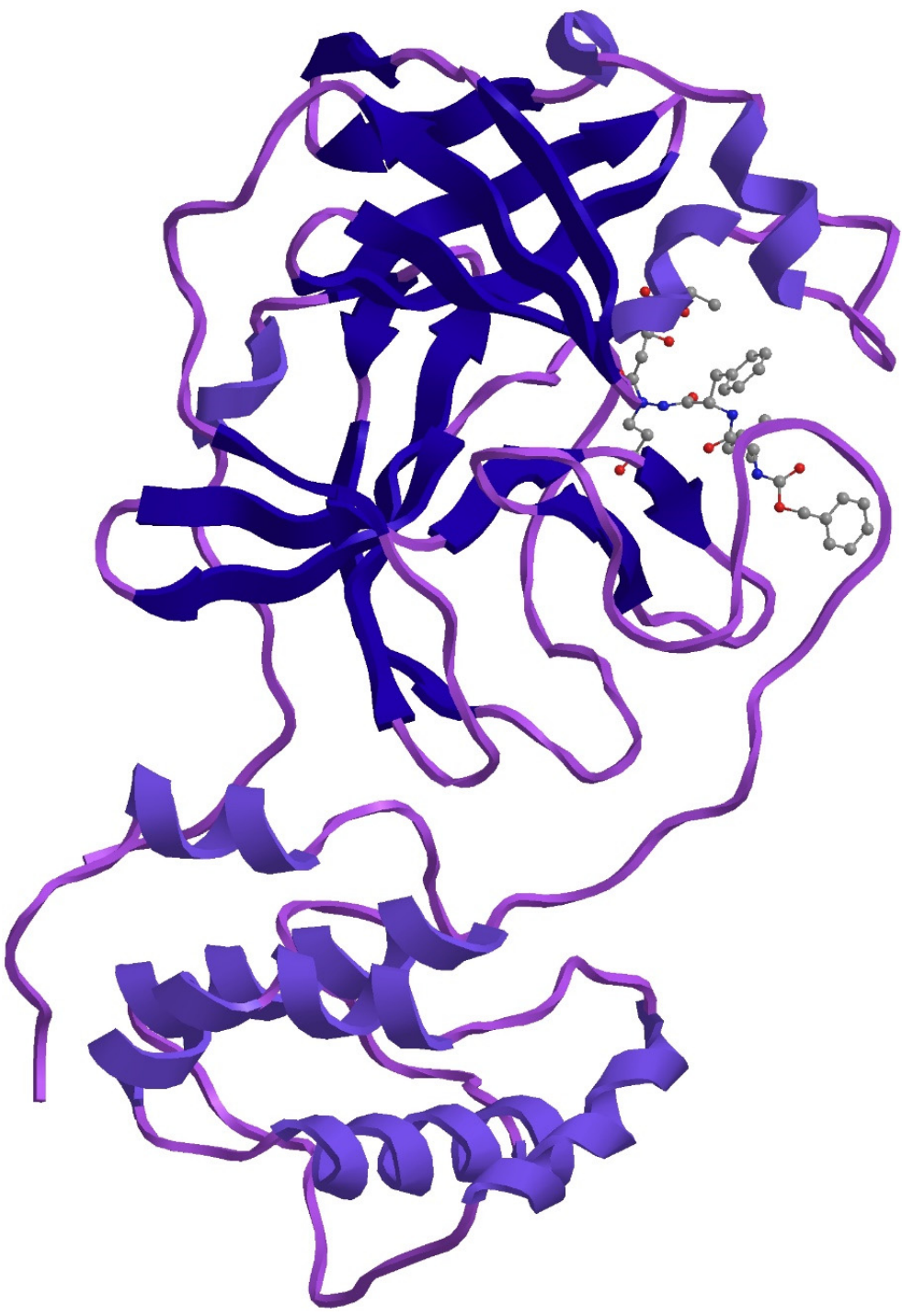

406

Fig. 4 Homology model with ligand binding of protein from amino acids 3268 -3573 in Frame 2 with 306 amino acids of the Complete genome sequence of the SARS-CoV-2 virus isolate Wuhan-Hu-1 (Genbank Accession Number MN908947.3) which has 29903 bp linear ss-RNA with $2 \mathrm{a} 5 \mathrm{i}$ of the PDB database as template. 


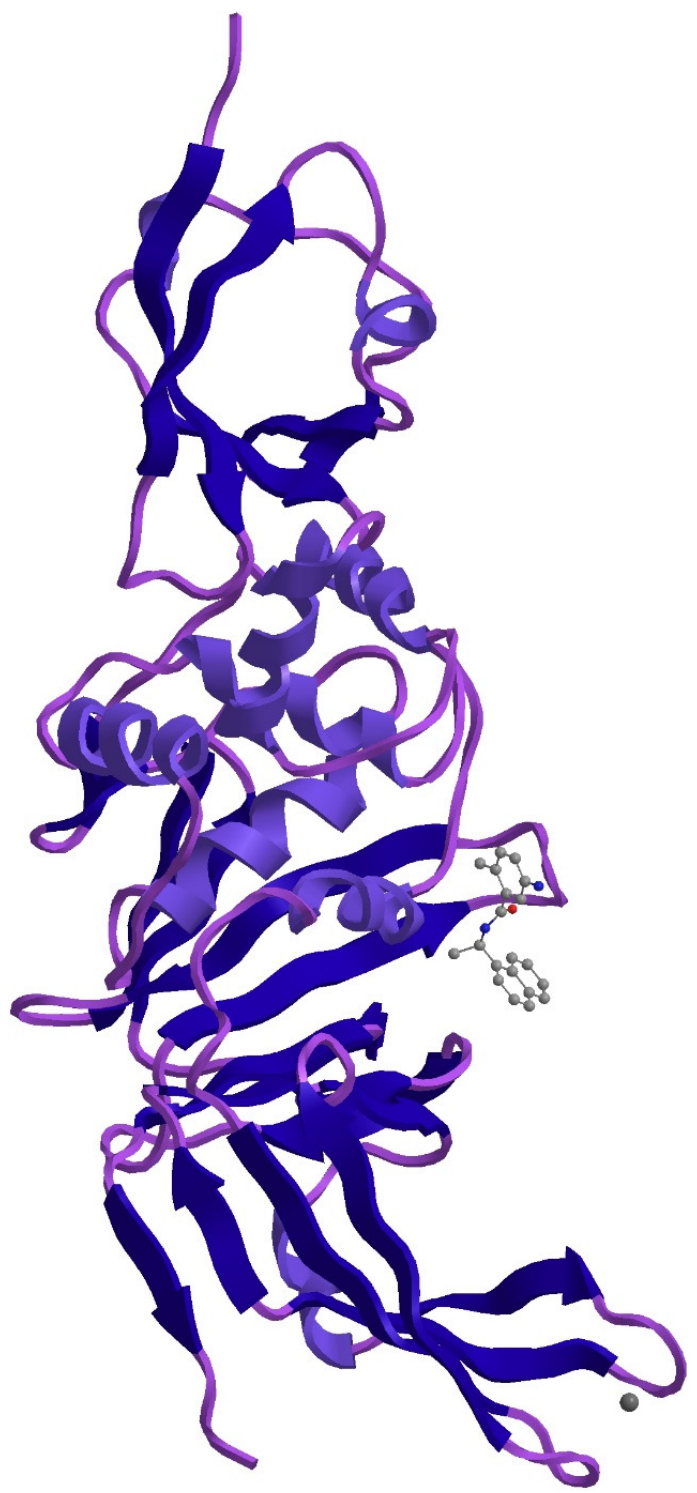

416 Fig. 5 Homology model with ligand binding of protein from residues 1568-1882 in Frame 2 with 315 amino acids of the Complete genome sequence of the SARS-CoV-2 virus isolate Wuhan-Hu-1 (Genbank Accession Number MN908947.3) which has 29903 bp linear ss-RNA with 3e9s of the PDB database as template. 
422

2a5i.1. (AB)

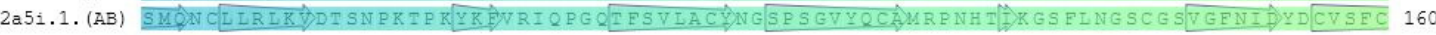
Seqres YMHHMELPTGVHAGTDLEGREYGPFDRQTAQAAGTDITITLNVLAWLYAAVINGDRWELNRTITLNDFNLVAMRYNYE 24O

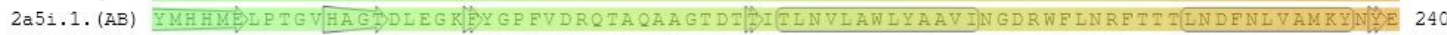
Seqres PLTQDHVDILGRLSAQTGIAVLDMCAALKELIQNGMNGRTILGSTILEDEFTPEDVVRQCSGVTFQ 306

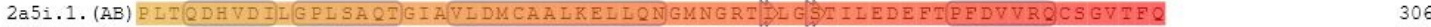

424 Fig. 6 Alignment of the 305 residues from 3268-3573 aa of the Novel Coronavirus COVI-19

425 with the template $2 \mathrm{a} 5 \mathrm{i}$

Seqres ASMEVRTIRVETTVDNTNLHTQLVDUSMTYGQQEGPTYLDGADVTKIKPHVNHEGKTFFVLPSDDTLRSEAFEYYHTLDESELGR 85

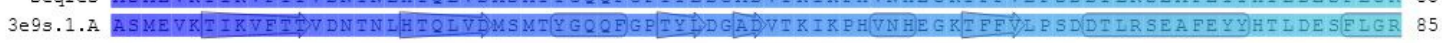
Seqres YUSALNHTRRWREPQVGGLTSIRWADNNCYLSSVLLALQQLEVRENARALQEAYYRARAGDAANECALILAYSNKIVGELGDVRE 170

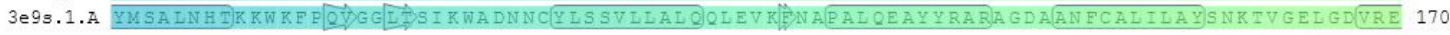
Seqres TMTHLLQHANLESAKRVINVVCKHCGQRTITLTGVEAVMYMGTLSYDNIRTGVSIPCVCGRDATQYLVQQESSFVMMSARPAEYR 255

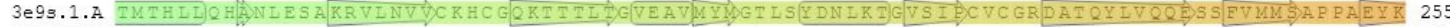
Seqres LQQGTELCANEYTGNYQCGHYTHITAKETLYRIDGAHLTRMSEYRGRVTDVFYKETSYTITIR

427 Fig.7 the alignment of the 315 residues from 1568-1882 aa of the Novel Coronavirus COVI- 


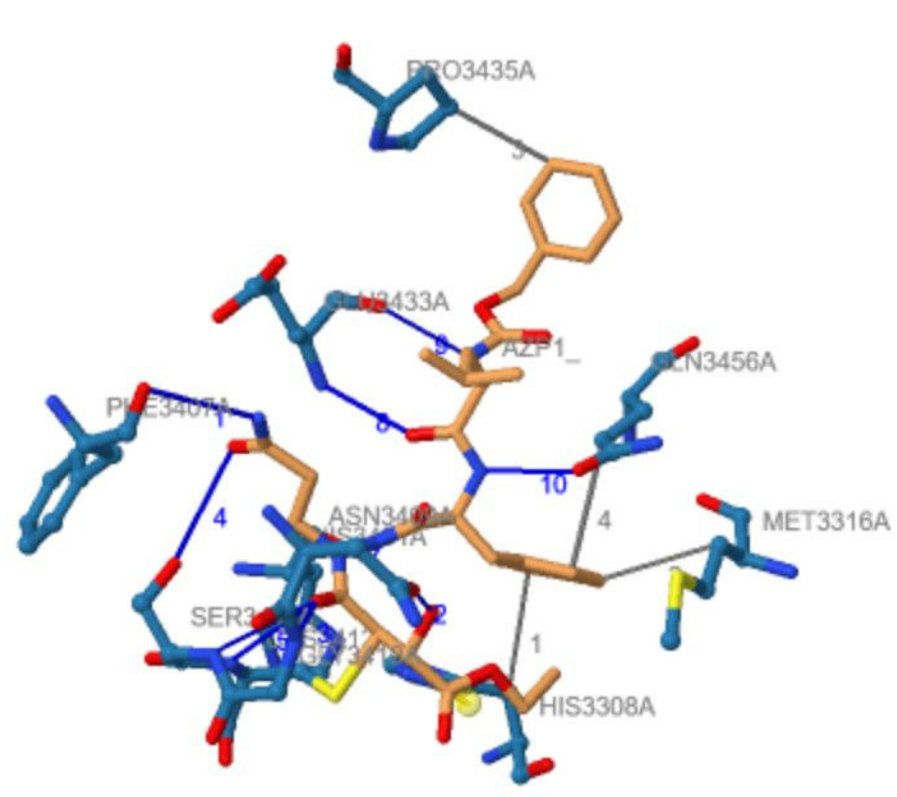

I." Protein

ininand

- Water

Charge Center Aromatic Ring Center

- Metal lon

.. Hydrophobic Interaction

- Hydrogen Bond

- Water Bridge

... $\pi$-Stacking (parallel)

$\cdots \pi$-Stacking (perpendicular)

... $\pi$-Cation Interaction

- Halogen Bond

.. Salt Bridge

-. Metal Complexation

430 Fig.8 Protein Ligand interaction between the C3 like peptidase with aza-peptide epoxide of the model with the template $2 \mathrm{a} 5 \mathrm{i}$ 


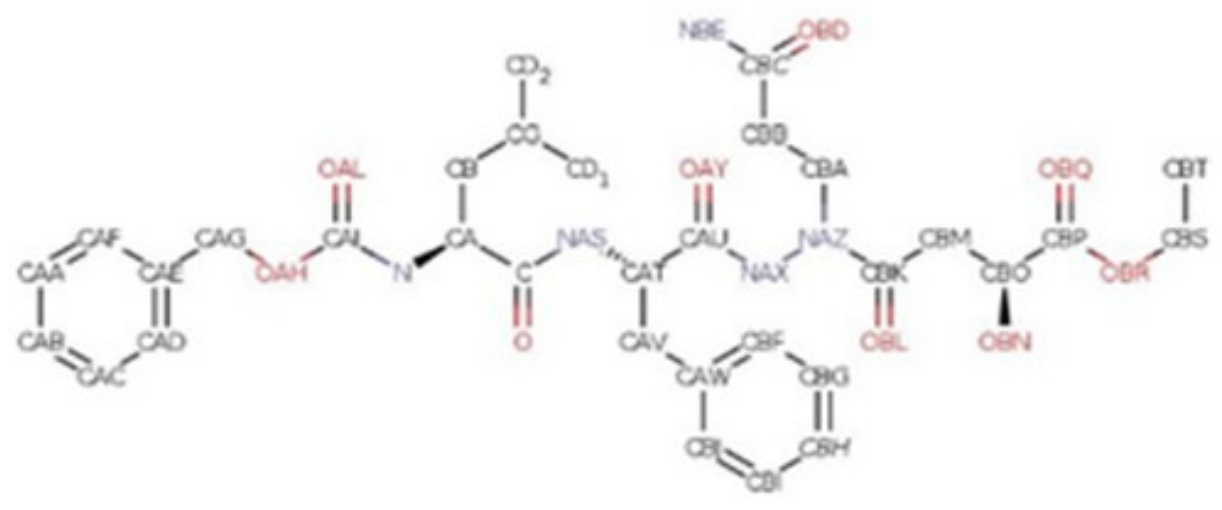

432

433 Fig. 9 Structure of Aza-Peptide Epoxide (APE) ethyl (2S)-4-[(3-amino-3-oxo-propyl)-[[(2S)-

434 2-[[(2S)-4-methyl-2-phenylmethoxycarbonylamino-pentanoyl]amino]-3-phenyl-

435 propanoyl]amino]amino]-2-hydroxy-4-oxo-butanoate with possible anti Coronavirus

436 activity - (Source https://www.rcsb.org/ligand/AZP) 


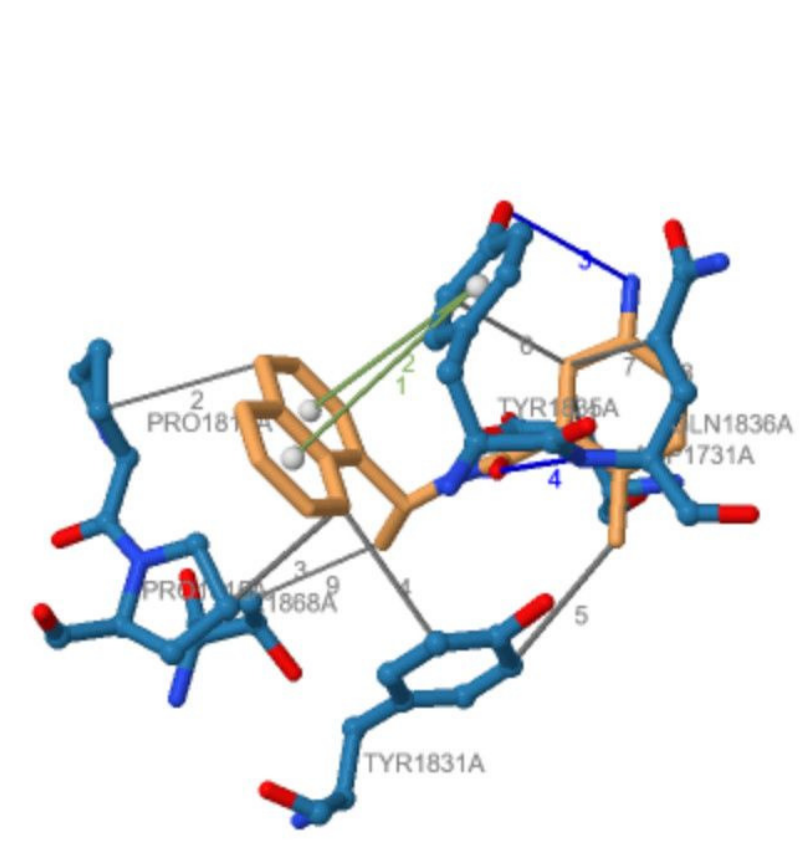

-... Protein

in: Ligand

Water
Charge Center Aromatic Ring Center
- Metal lon
... Hydrophobic Interaction
- Hydrogen Bond
- Water Bridge
... $\pi$-Stacking (parallel)
$\cdots \pi$-Stacking (perpendicular)
$\cdots \pi$-Cation Interaction
- Halogen Bond
... Salt Bridge
-.. Metal Complexation

Fig.10 Protein Ligand interaction between the Novel Coronavirus non structural protein and papain-like protease of the model with the template $3 \mathrm{e} 9 \mathrm{~s}$ 


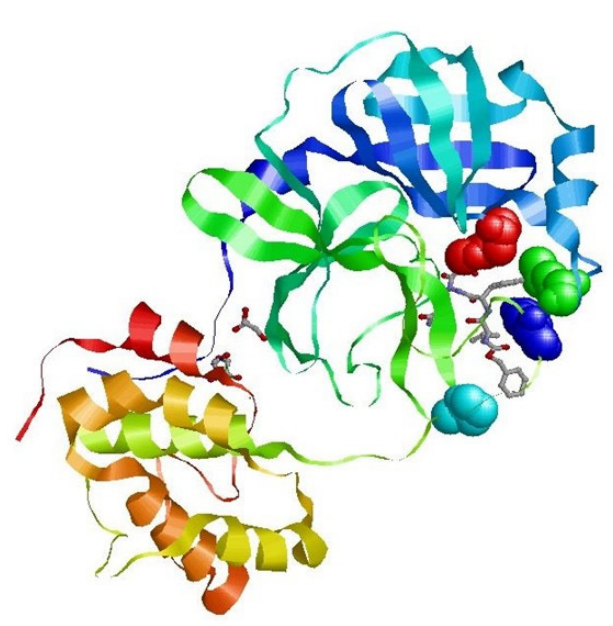

2a5i_Template

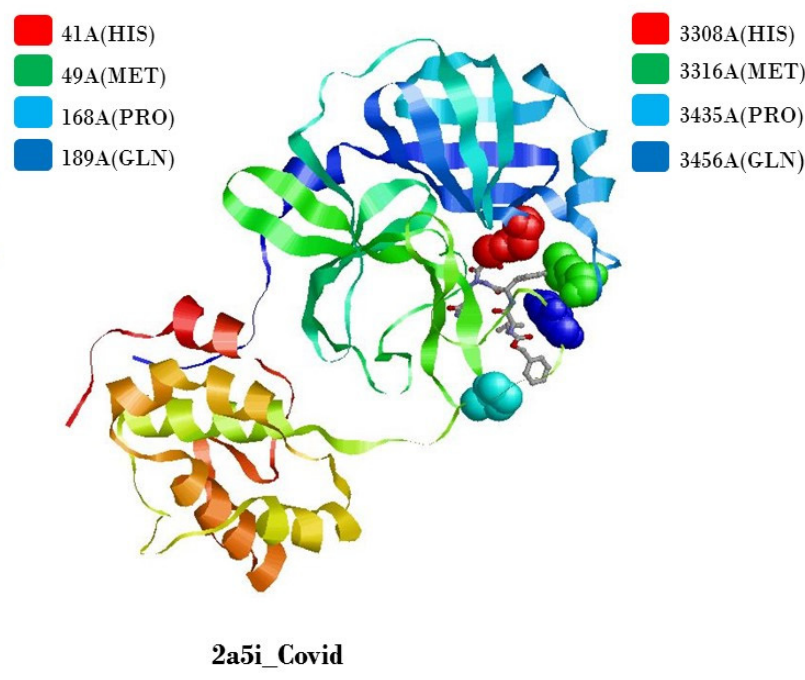

451

452

453

454

455

456

457

458

459

460 


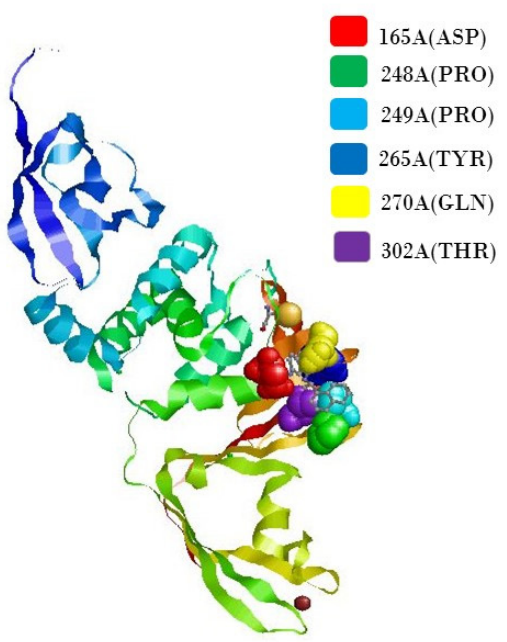

3e9s_Template

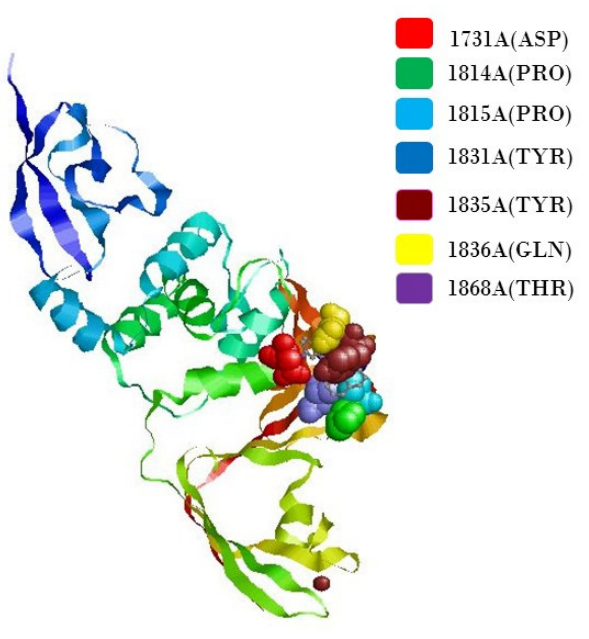

3e9s_Covid

467 Fig.12 comparison of the hydrophobic interaction of the biding of the ligand AZP between the 


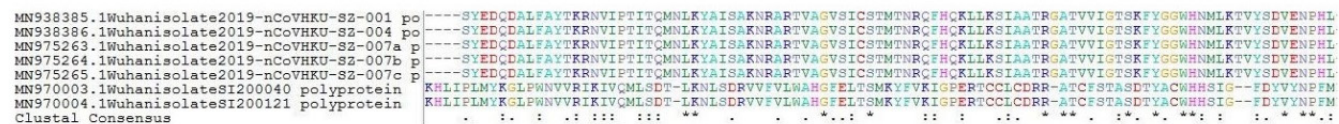

471

472 Supplementary Fig.1 Multiple alignment of the Polyproteins of Severe acute respiratory

473 syndrome coronavirus 2 isolate virus isolates

474

475

476 
Table 1 Physico-chemical properties of polyproteins of SARS-CoV-2 virus isolates

\begin{tabular}{|c|c|c|c|c|c|c|c|}
\hline $\begin{array}{l}\text { Accession } \\
\text { Number }\end{array}$ & $\begin{array}{l}\text { MN9383 } \\
85.1\end{array}$ & $\begin{array}{l}\text { MN93838 } \\
6.1\end{array}$ & $\begin{array}{l}\text { MN97526 } \\
3.1\end{array}$ & $\begin{array}{l}\text { MN97526 } \\
4.1\end{array}$ & $\begin{array}{l}\text { MN97526 } \\
5.1\end{array}$ & $\begin{array}{l}\text { MN97000 } \\
3.1\end{array}$ & $\begin{array}{l}\text { MN9700 } \\
04.1\end{array}$ \\
\hline $\begin{array}{l}\text { Reading } \\
\text { Frame }\end{array}$ & 3 & 3 & 3 & 3 & 3 & 2 & 2 \\
\hline $\begin{array}{l}\text { Number } \\
\text { of amino } \\
\text { acids }\end{array}$ & 95 & 95 & 95 & 95 & 95 & 96 & 96 \\
\hline $\begin{array}{l}\text { Molecular } \\
\text { weight }\end{array}$ & 10640.22 & 10640.22 & 10640.22 & 10640.22 & 10640.22 & 11239.26 & 11239.26 \\
\hline $\begin{array}{l}\text { Theoretica } \\
1 \mathrm{pI}\end{array}$ & 9.87 & 9.87 & 9.87 & 9.87 & 9.87 & 8.9 & 8.9 \\
\hline Formula & $\begin{array}{l}\mathrm{C}_{472} \mathrm{H}_{752} \\
\mathrm{~N}_{134} \mathrm{O}_{138} \\
\mathrm{~S}_{4} \\
\end{array}$ & $\begin{array}{l}\mathrm{C}_{472} \mathrm{H}_{752} \mathrm{~N} \\
{ }_{134} \mathrm{O}_{138} \mathrm{~S}_{4}\end{array}$ & $\begin{array}{l}\mathrm{C}_{472} \mathrm{H}_{752} \mathrm{~N} \\
{ }_{134} \mathrm{O}_{138} \mathrm{~S}_{4}\end{array}$ & $\begin{array}{l}\mathrm{C}_{472} \mathrm{H}_{752} \mathrm{~N}_{1} \\
{ }_{34} \mathrm{O}_{138} \mathrm{~S}_{4}\end{array}$ & $\begin{array}{l}\mathrm{C}_{472} \mathrm{H}_{752} \mathrm{~N} \\
{ }_{134} \mathrm{O}_{138} \mathrm{~S}_{4}\end{array}$ & $\begin{array}{l}\mathrm{C}_{516} \mathrm{H}_{786} \mathrm{~N} \\
{ }_{132} \mathrm{O}_{132} \mathrm{~S}_{9}\end{array}$ & $\begin{array}{l}\mathrm{C}_{516} \mathrm{H}_{786} \\
\mathrm{~N}_{132} \mathrm{O}_{132} \mathrm{~S} \\
9\end{array}$ \\
\hline $\begin{array}{l}\text { Total } \\
\text { number of } \\
\text { atoms }\end{array}$ & 1500 & 1500 & 1500 & 1500 & 1500 & 1575 & 1575 \\
\hline $\begin{array}{l}\text { Extinction } \\
\text { coefficient } \\
\mathrm{s}\end{array}$ & 12950 & 12950 & 12950 & 12950 & 12950 & 24200 & 24200 \\
\hline $\begin{array}{l}\text { Instability } \\
\text { index }\end{array}$ & 20.51 & 20.51 & 20.51 & 20.51 & 20.51 & 29.66 & 29.66 \\
\hline $\begin{array}{l}\text { Aliphatic } \\
\text { index }\end{array}$ & 80.11 & 80.11 & 80.11 & 80.11 & 80.11 & 89.27 & 89.27 \\
\hline $\begin{array}{l}\text { Grand } \\
\text { average of } \\
\text { hydropathi } \\
\text { city } \\
\text { (GRAVY) }\end{array}$ & -0.264 & -0.264 & -0.264 & -0.264 & -0.264 & 0.161 & 0.161 \\
\hline $\begin{array}{l}\text { Estimated } \\
\text { half-life }\end{array}$ & $\begin{array}{l}1.9 \text { hours } \\
\text { (mammal }\end{array}$ & $\begin{array}{l}1.9 \text { hours } \\
\text { (mammali }\end{array}$ & $\begin{array}{l}1.9 \text { hours } \\
\text { (mammali }\end{array}$ & $\begin{array}{l}1.9 \text { hours } \\
\text { (mammali }\end{array}$ & $\begin{array}{l}1.9 \text { hours } \\
\text { (mammali }\end{array}$ & $\begin{array}{l}1.3 \text { hours } \\
\text { (mammali }\end{array}$ & $\begin{array}{l}1.3 \text { hours } \\
\text { (mammal }\end{array}$ \\
\hline
\end{tabular}




\begin{tabular}{|l|l|l|l|l|l|l|l|}
\hline & $\begin{array}{l}\text { ian } \\
\text { reticuloc } \\
\text { ytes, in } \\
\text { vitro). }\end{array}$ & $\begin{array}{l}\text { an } \\
\text { reticulocy } \\
\text { tes, in } \\
\text { vitro). }\end{array}$ & $\begin{array}{l}\text { an } \\
\text { reticulocy } \\
\text { tes, in } \\
\text { vitro). }\end{array}$ & $\begin{array}{l}\text { an } \\
\text { reticulocyt } \\
\text { es, in } \\
\text { vitro). }\end{array}$ & $\begin{array}{l}\text { an } \\
\text { reticulocy } \\
\text { tes, in } \\
\text { vitro). }\end{array}$ & $\begin{array}{l}\text { an } \\
\text { reticulocy } \\
\text { tes, in } \\
\text { vitro). }\end{array}$ & $\begin{array}{l}\text { ian } \\
\text { reticulocy } \\
\text { tes, in } \\
\text { vitro). }\end{array}$ \\
\hline $\begin{array}{l}>20 \\
\text { hours } \\
\text { (yeast, in } \\
\text { vivo). } \\
\text { hours } \\
\text { (yeast, in } \\
\text { vivo). }\end{array}$ & $\begin{array}{l}>20 \text { hours } \\
\text { (yeast, in } \\
\text { vivo). }\end{array}$ & $\begin{array}{l}>20 \\
\text { (yeast, in } \\
\text { vivo). } \\
\text { hours } \\
\text { (yeast, in } \\
\text { vivo). }\end{array}$ & $\begin{array}{l}3 \text { min } \\
\text { (yeast, in } \\
\text { vivo). }\end{array}$ & $\begin{array}{l}3 \text { min } \\
\text { (yeast, in } \\
\text { vivo). }\end{array}$ \\
\hline $\begin{array}{l}>10 \\
\text { hours } \\
\text { (Escheric } \\
\text { hia coli, } \\
\text { in vivo). }\end{array}$ & $\begin{array}{l}\text { hours } \\
\text { (Escheric } \\
\text { hia coli, } \\
\text { in vivo). }\end{array}$ & & & & & & \\
\hline
\end{tabular}


Table 2 Tertiary Structure of SARS-CoV-2 virus isolate SARS-COV-2_HKU-SZ-001_2020 ORF1ab polyprotein alignment with templates

\begin{tabular}{|c|c|c|}
\hline $\begin{array}{l}\text { PDB } \\
\text { Template }\end{array}$ & Gene & Identity \\
\hline 6nur.1.A & NSP12 & 98.947 \\
\hline 1khv.1.A & $\begin{array}{l}\text { RNA-directed RNA } \\
\text { polymerase }\end{array}$ & 8.97 \\
\hline 1khv.2.A & $\begin{array}{l}\text { RNA-directed RNA } \\
\text { polymerase }\end{array}$ & 8.97 \\
\hline 5z6v.1.A & $\begin{array}{l}\text { ABC-type } \\
\text { uncharacterized } \\
\text { transport system } \\
\text { periplasmic } \\
\text { component-like } \\
\text { protein }\end{array}$ & 19.74 \\
\hline
\end{tabular}




\begin{tabular}{|c|c|c|}
\hline 6k1y.1.A & $\begin{array}{l}\text { ABC-type } \\
\text { uncharacterized } \\
\text { transport system } \\
\text { periplasmic } \\
\text { component-like } \\
\text { protein }\end{array}$ & 19.74 \\
\hline 2ckw.1.A & $\begin{array}{l}\text { RNA-directed RNA } \\
\text { polymerase }\end{array}$ & 10.53 \\
\hline 2uuw.1.A & $\begin{array}{l}\text { RNA-directed RNA } \\
\text { polymerase }\end{array}$ & 10.67 \\
\hline 2wk4.1.A & $\begin{array}{l}\text { Protease-polymerase } \\
\text { p70 }\end{array}$ & 10.67 \\
\hline 2wk4.1.B & $\begin{array}{l}\text { Protease-polymerase } \\
\text { p70 }\end{array}$ & 10.67 \\
\hline 2yan.1.A & Glutaredoxin-3 & 12.50 \\
\hline 2yan.2.A & Glutaredoxin-3 & 12.50 \\
\hline
\end{tabular}


Table 3 Main Protein with a sequence length - 4409aa of SARS-CoV-2 Virus showing structural alignment with two other proteins of SARS-CoV

\begin{tabular}{|c|c|c|c|c|c|}
\hline $\begin{array}{l}\text { Template } \\
\text { ID }\end{array}$ & Template Title & $\begin{array}{l}\text { Alignment } \\
\text { Positions }\end{array}$ & $\begin{array}{l}\text { Number of } \\
\text { aa }\end{array}$ & Ligands & Interacting Residues \\
\hline $3 \mathrm{e} 9 \mathrm{~s} .1$ & $\begin{array}{l}\text { A new class of } \\
\text { papain-like } \\
\text { protease/deubi } \\
\text { quitinase } \\
\text { inhibitors } \\
\text { blocks SARS } \\
\text { virus } \\
\text { replication }\end{array}$ & $1568-1882$ & 315 & TTT & $\begin{array}{l}\text { Chain } \\
\text { A: L.1729, G.1730, D.1731, P } \\
.1814, \text { P.1815, Y.1831, Y.183 } \\
\text { 5, Q.1836, Y.1840, T.1868 }\end{array}$ \\
\hline $2 \mathrm{a} 5 \mathrm{i} .1$ & $\begin{array}{l}\text { Crystal } \\
\text { structures of } \\
\text { SARS } \\
\text { coronavirus } \\
\text { main peptidase } \\
\text { inhibited by an } \\
\text { aza-peptide } \\
\text { epoxide in the } \\
\text { space group C2 }\end{array}$ & $3268-3573$ & 306 & AZP & $\begin{array}{l}\text { Chain } \\
\text { A: T.3292, T.3293, H.3308, } \\
\text { M.3316, Y.3321, F.3407, L.34 } \\
\text { 08, N.3409, G.3410, S.3411, } \\
\text { C.3412, H.3430, H.3431, M.3 } \\
\text { 432, E.3433, P.3435, H.3439, } \\
\text { D.3454, R.3455, Q.3456, T.34 } \\
\text { 57, A.3458, Q.3459 }\end{array}$ \\
\hline
\end{tabular}


Table 4 Statistics of structural comparison with PDB templates

\begin{tabular}{|l|l|l|l|l|l|l|}
\hline Structure & Template & Similarity & p-Value & $\begin{array}{l}\text { No. } \\
\text { equivalent } \\
\text { positions }\end{array}$ & RMSD & $\begin{array}{l}\text { Raw } \\
\text { Score }\end{array}$ \\
\hline 3e9s_covid & $3 \mathrm{e} 9 \mathrm{~s}$ & $\begin{array}{l}\text { Significantly } \\
\text { Similar }\end{array}$ & $0.00 \mathrm{e}+00$ & 314 & 0.10 & 935.61 \\
\hline 2a5i_covid & $2 \mathrm{a} 5 \mathrm{i}$ & $\begin{array}{l}\text { Significantly } \\
\text { Similar }\end{array}$ & $0.00 \mathrm{e}+00$ & 306 & 0.08 & 911.72 \\
\hline
\end{tabular}


Supplementary Table 1 List of Severe Acute Respiratory Syndrome coronavirus 2 isolate sequences taken for bioinformatic analysis

\begin{tabular}{|c|c|c|}
\hline Genbank Accession Number & Title & Description \\
\hline MN988713.1 & Severe acute respiratory syndrome coronavirus 2 isolate $2019-\mathrm{nCoV} / \mathrm{USA}-\mathrm{IL} 1 / 2020$ & Complete genome \\
\hline MN938384.1 & Severe acute respiratory syndrome coronavirus 2 isolate $2019-\mathrm{nCoV}$ _HKU-SZ-002a_2020 & Complete genome \\
\hline MN975262.1 & Severe acute respiratory syndrome coronavirus 2 isolate $2019-\mathrm{nCoV} \_\mathrm{HKU}-\mathrm{SZ}-005 \mathrm{~b} 2020$ & Complete genome \\
\hline MN985325.1 & Severe acute respiratory syndrome coronavirus 2 isolate $2019-\mathrm{nCoV} / \mathrm{USA}-\mathrm{WA} 1 / 2020$ & Complete genome \\
\hline NC_045512.2 & Wuhan seafood market pneumonia virus isolate Wuhan-Hu-1 & Complete genome \\
\hline MN908947.3 & Severe acute respiratory syndrome coronavirus 2 isolate Wuhan-Hu-1 & Complete genome \\
\hline MN938385.1 & $\begin{array}{l}\text { Severe acute respiratory syndrome coronavirus } 2 \text { isolate 2019-nCoV_HKU-SZ-001_2020 ORF1ab polyprotein, } \\
\text { RdRp region, (orflab) gene, partial cds }\end{array}$ & Polyprotein, RdRp region \\
\hline MN938386.1 & $\begin{array}{l}\text { Severe acute respiratory syndrome coronavirus } 2 \text { isolate 2019-nCoV_HKU-SZ-004_2020 ORF1ab polyprotein, } \\
\text { RdRp region, (orflab) gene, partial cds }\end{array}$ & Polyprotein, RdRp region \\
\hline MN975263.1 & $\begin{array}{l}\text { Severe acute respiratory syndrome coronavirus } 2 \text { isolate 2019-nCoV_HKU-SZ-007a_2020 ORF1ab polyprotein, } \\
\text { RdRp region, (orflab) gene, partial cds }\end{array}$ & Polyprotein, RdRp region \\
\hline MN975264.1 & $\begin{array}{l}\text { Severe acute respiratory syndrome coronavirus } 2 \text { isolate 2019-nCoV_HKU-SZ-007b_2020 ORF1ab polyprotein, } \\
\text { RdRp region, (orflab) gene, partial cds }\end{array}$ & Polyprotein, RdRp region \\
\hline MN975265.1 & $\begin{array}{l}\text { Severe acute respiratory syndrome coronavirus } 2 \text { isolate } 2019-\mathrm{nCoV} \_\mathrm{HKU}-\mathrm{SZ}-007 \mathrm{c} \_2020 \text { ORF1ab polyprotein, } \\
\text { RdRp region, (orflab) gene, partial cds }\end{array}$ & Polyprotein, RdRp region \\
\hline MN970003.1 & $\begin{array}{l}\text { Severe acute respiratory syndrome coronavirus } 2 \text { isolate SI200040-SP orflab polyprotein, RdRP region, (orflab) } \\
\text { gene, partial cds }\end{array}$ & Polyprotein, RdRp region \\
\hline
\end{tabular}




\begin{tabular}{|c|c|c|}
\hline MN970004.1 & $\begin{array}{l}\text { Severe acute respiratory syndrome coronavirus } 2 \text { isolate SI200121-SP orflab polyprotein, RdRP region, (orflab) } \\
\text { gene, partial cds }\end{array}$ & Polyprotein, $\mathrm{RdRp}$ region \\
\hline MN938387.1 & $\begin{array}{l}\text { Severe acute respiratory syndrome coronavirus } 2 \text { isolate 2019-nCoV_HKU-SZ-001_2020 surface glycoprotein } \\
\text { (S) gene, partial cds }\end{array}$ & Glycoprotein \\
\hline MN938388.1 & $\begin{array}{l}\text { Severe acute respiratory syndrome coronavirus } 2 \text { isolate 2019-nCoV_HKU-SZ-002b_2020 surface glycoprotein } \\
\text { (S) gene, partial cds }\end{array}$ & Glycoprotein \\
\hline MN938389.1 & $\begin{array}{l}\text { Severe acute respiratory syndrome coronavirus } 2 \text { isolate 2019-nCoV_HKU-SZ-004_2020 surface glycoprotein } \\
\text { (S) gene, partial cds }\end{array}$ & Glycoprotein \\
\hline MN938390.1 & $\begin{array}{l}\text { Severe acute respiratory syndrome coronavirus } 2 \text { isolate 2019-nCoV_HKU-SZ-005_2020 surface glycoprotein } \\
\text { (S) gene, partial cds }\end{array}$ & Glycoprotein \\
\hline MN975267.1 & $\begin{array}{l}\text { Severe acute respiratory syndrome coronavirus } 2 \text { isolate 2019-nCoV_HKU-SZ-007b_2020 surface glycoprotein } \\
\text { (S) gene, partial cds }\end{array}$ & Glycoprotein \\
\hline MN975268.1 & $\begin{array}{l}\text { Severe acute respiratory syndrome coronavirus } 2 \text { isolate } 2019-\mathrm{nCoV} \_ \text {HKU-SZ-007c_2020 surface glycoprotein } \\
\text { (S) gene, partial cds }\end{array}$ & Glycoprotein \\
\hline
\end{tabular}


Supplementary Table 2 Comparison of binding properties of Novel Coronavirus protein from region 3268-3573 (2a5i_SARS-CoV-2) and 2a5i template to ligand AZP

Hydrophobic Interactions

\begin{tabular}{|c|c|c|c|c|c|c|c|c|c|c|}
\hline Index & \multicolumn{2}{|l|}{ Residue } & \multicolumn{2}{|l|}{ AA } & \multicolumn{2}{|l|}{ Distance } & \multicolumn{2}{|l|}{ Ligand Atom } & \multicolumn{2}{|l|}{ Protein Atom } \\
\hline & 2a5i SARS-CoV-2 & $2 \mathrm{a} 5 \mathrm{i}$ & 2a5i SARS-CoV-2 & $2 \mathrm{a} 5 \mathrm{i}$ & 2a5i SARS-CoV-2 & $2 \mathrm{a} 5 \mathrm{i}$ & 2a5i SARS-CoV-2 & $2 \mathrm{a} 5 \mathrm{i}$ & 2a5i SARS-CoV-2 & $2 \mathrm{a} 5 \mathrm{i}$ \\
\hline 1 & $3308 \mathrm{~A}$ & $41 \mathrm{~A}$ & HIS & HIS & 3.64 & 3.70 & 2393 & 2461 & 307 & 308 \\
\hline 2 & $3316 \mathrm{~A}$ & $49 \mathrm{~A}$ & MET & MET & 3.81 & 3.86 & 2395 & 2463 & 368 & 368 \\
\hline 3 & $3435 \mathrm{~A}$ & $168 \mathrm{~A}$ & PRO & PRO & 3.42 & 3.73 & 2376 & 2443 & 1303 & 1347 \\
\hline 4 & $3456 \mathrm{~A}$ & $189 \mathrm{~A}$ & GLN & GLN & 3.84 & 3.93 & 2396 & 2464 & 1462 & 1507 \\
\hline
\end{tabular}

Hydrogen Bonds

\begin{tabular}{|c|c|c|c|c|c|c|c|c|c|c|c|c|c|c|c|c|c|c|}
\hline Index & \multicolumn{2}{|c|}{ Residue } & \multicolumn{2}{|c|}{ AA } & \multicolumn{2}{|c|}{ Distance H-A } & \multicolumn{2}{|c|}{ Distance D-A } & \multicolumn{2}{|c|}{ Donor Angle } & \multicolumn{2}{|c|}{ Protein donor? } & \multicolumn{2}{|c|}{ Sidechain } & \multicolumn{2}{|c|}{ Donor Atom } & \multicolumn{2}{|c|}{ Acceptor Atom } \\
\hline & $\begin{array}{c}2 \mathrm{a} 5 \mathrm{i} \\
\mathrm{SAR} \\
-\mathrm{S}- \\
\mathrm{CoV}-2\end{array}$ & $2 \mathrm{a} 5 \mathrm{i}$ & $\begin{array}{c}2 \mathrm{a} 5 \mathrm{i} \\
\text { SAR } \\
-\mathrm{S}- \\
\mathrm{CoV}-2\end{array}$ & $2 \mathrm{a} 5 \mathrm{i}$ & $\begin{array}{c}2 \mathrm{a} 5 \mathrm{i} \\
\text { SAR } \\
-\mathrm{S}- \\
\mathrm{S}- \\
\mathrm{CoV}-2\end{array}$ & $2 \mathrm{a} 5 \mathrm{i}$ & $\begin{array}{c}2 \mathrm{a} 5 \mathrm{i} \\
\text { SAR } \\
-\mathrm{S}- \\
\mathrm{CoV}-2\end{array}$ & $2 \mathrm{a} 5 \mathrm{i}$ & $\begin{aligned} & 2 \mathrm{a} 5 \mathrm{i} \\
& \text { SARS } \\
& \text {-CoV-2 }\end{aligned}$ & $2 \mathrm{a} 5 \mathrm{i}$ & $\begin{array}{c}2 \mathrm{a} 5 \mathrm{i} \\
\mathrm{SAR} \\
-\mathrm{S}- \\
\mathrm{CoV}-2\end{array}$ & $2 \mathrm{a} 5 \mathrm{i}$ & $\begin{array}{c}2 \mathrm{a} 5 \mathrm{i} \\
\mathrm{SAR} \\
-\mathrm{S}- \\
\mathrm{CoV}-2\end{array}$ & $2 \mathrm{a} 5 \mathrm{i}$ & $\begin{array}{c}2 \mathrm{a} 5 \mathrm{i} \\
\mathrm{SAR} \\
-\mathrm{S}- \\
\mathrm{CoV}-2\end{array}$ & $2 \mathrm{a} 5 \mathrm{i}$ & $\begin{array}{c}2 \mathrm{a} 5 \mathrm{i} \\
\text { SARS } \\
-\mathrm{-CoV}-2\end{array}$ & $2 \mathrm{a} 5 \mathrm{i}$ \\
\hline 1 & $3407 \mathrm{~A}$ & $140 \mathrm{~A}$ & PHE & PHE & 2.61 & 2.46 & 3.47 & 3.33 & 146.60 & $\begin{array}{l}147.2 \\
8\end{array}$ & 点 & x & 点 & 政 & $\begin{array}{l}2404 \\
{[\mathrm{Nam}]}\end{array}$ & $\begin{array}{l}2472 \\
{[\mathrm{Nam}]}\end{array}$ & $\begin{array}{l}1081 \\
{[\mathrm{O} 2]}\end{array}$ & $\begin{array}{l}1112 \\
{[\mathrm{O} 2]}\end{array}$ \\
\hline 2 & 3409A & $142 \mathrm{~A}$ & ASN & ASN & 2.51 & 2.52 & 2.87 & 2.87 & 102.18 & $\begin{array}{l}100.9 \\
3\end{array}$ & 次 & x & $\checkmark$ & $\checkmark$ & $\begin{array}{l}2410 \\
\text { [O3] }\end{array}$ & $\begin{array}{l}2478 \\
{[\mathrm{O} 3]}\end{array}$ & $\begin{array}{l}1103 \\
{[\mathrm{O} 2]}\end{array}$ & $\begin{array}{l}1134 \\
{[\mathrm{O} 2]}\end{array}$ \\
\hline
\end{tabular}




\begin{tabular}{|c|c|c|c|c|c|c|c|c|c|c|c|c|c|c|c|c|c|c|}
\hline 3 & $3410 \mathrm{~A}$ & $143 \mathrm{~A}$ & GLY & GLY & 1.94 & 1.83 & 2.78 & 2.73 & 142.36 & $\begin{array}{l}150.5 \\
7\end{array}$ & $\checkmark$ & $\checkmark$ & X & X & $\begin{array}{l}1105 \\
{[\mathrm{Nam}]}\end{array}$ & $\begin{array}{l}1136 \\
{[\mathrm{Nam}]}\end{array}$ & $\begin{array}{l}2407 \\
{[\mathrm{O} 2]}\end{array}$ & $\begin{array}{l}2475 \\
{[\mathrm{O} 2]}\end{array}$ \\
\hline 4 & $3411 \mathrm{~A}$ & $144 \mathrm{~A}$ & SER & SER & 3.37 & 3.44 & 3.76 & 3.80 & 106.27 & $\begin{array}{l}104.7 \\
9\end{array}$ & $\vartheta$ & $\vartheta$ & $\vartheta$ & $\checkmark$ & $\begin{array}{l}1114 \\
{[\mathrm{O} 3]}\end{array}$ & $\begin{array}{l}1145 \\
{[\mathrm{O} 3]}\end{array}$ & $\begin{array}{l}2405 \\
{[\mathrm{O} 2]}\end{array}$ & $\begin{array}{l}2473 \\
{[\mathrm{O} 2]}\end{array}$ \\
\hline 5 & $3411 \mathrm{~A}$ & $144 \mathrm{~A}$ & SER & SER & 2.60 & 2.61 & 3.24 & 3.20 & 122.58 & $\begin{array}{l}118.2 \\
3\end{array}$ & $v$ & $v$ & $x$ & X & $\begin{array}{l}1109 \\
{[\mathrm{Nam}]}\end{array}$ & $\begin{array}{l}1140 \\
{[\mathrm{Nam}]}\end{array}$ & $\begin{array}{l}2407 \\
{[\mathrm{O} 2]}\end{array}$ & $\begin{array}{l}2475 \\
{[\mathrm{O} 2]}\end{array}$ \\
\hline 6 & $3412 \mathrm{~A}$ & $145 \mathrm{~A}$ & CYS & CYS & 2.50 & 2.57 & 3.39 & 3.37 & 150.10 & $\begin{array}{l}137.9 \\
6\end{array}$ & $\vartheta$ & $\vartheta$ & X & X & $\begin{array}{l}1115 \\
{[\mathrm{Nam}]}\end{array}$ & $\begin{array}{l}1146 \\
{[\mathrm{Nam}]}\end{array}$ & $\begin{array}{l}2407 \\
{[\mathrm{O} 2]}\end{array}$ & $\begin{array}{l}2475 \\
{[\mathrm{O} 2]}\end{array}$ \\
\hline 7 & $3431 \mathrm{~A}$ & $164 \mathrm{~A}$ & HIS & HIS & 1.70 & 1.73 & 2.63 & 2.67 & 156.72 & $\begin{array}{l}157.3 \\
1\end{array}$ & X & $\sqrt{3}$ & x & X & $\begin{array}{l}2399 \\
{[\mathrm{Nam}]}\end{array}$ & $\begin{array}{l}2467 \\
\text { [Nam] }\end{array}$ & $\begin{array}{l}1266 \\
{[\mathrm{O} 2]}\end{array}$ & $\begin{array}{l}1307 \\
{[\mathrm{O} 2]}\end{array}$ \\
\hline 8 & $3433 \mathrm{~A}$ & $166 \mathrm{~A}$ & GLU & GLU & 2.08 & 2.01 & 3.04 & 2.97 & 165.52 & $\begin{array}{l}163.2 \\
2\end{array}$ & $v$ & $\vartheta$ & $x$ & X & $\begin{array}{l}1281 \\
\text { [Nam] }\end{array}$ & $\begin{array}{l}1325 \\
{[\mathrm{Nam}]}\end{array}$ & $\begin{array}{l}2387 \\
{[\mathrm{O} 2]}\end{array}$ & $\begin{array}{l}2455 \\
{[\mathrm{O} 2]}\end{array}$ \\
\hline 9 & $3433 \mathrm{~A}$ & $166 \mathrm{~A}$ & GLU & GLU & 2.06 & 2.13 & 2.88 & 2.92 & 140.23 & $\begin{array}{l}135.6 \\
7\end{array}$ & $x$ & $x$ & x & X & $\begin{array}{l}2370 \\
{[\mathrm{Nam}]}\end{array}$ & $\begin{array}{l}2438 \\
{[\mathrm{Nam}]}\end{array}$ & $\begin{array}{l}1284 \\
{[\mathrm{O} 2]}\end{array}$ & $\begin{array}{l}1328 \\
{[\mathrm{O} 2]}\end{array}$ \\
\hline 10 & $3456 \mathrm{~A}$ & $189 \mathrm{~A}$ & GLN & GLN & 1.90 & 1.82 & 2.84 & 2.77 & 158.82 & $\begin{array}{l}161.9 \\
3\end{array}$ & $x$ & $x$ & $v$ & $\checkmark$ & $\begin{array}{l}2388 \\
{[\mathrm{Nam}]}\end{array}$ & $\begin{array}{l}2456 \\
{[\mathrm{Nam}]}\end{array}$ & $\begin{array}{l}1464 \\
{[\mathrm{O} 2]}\end{array}$ & $\begin{array}{l}1509 \\
{[\mathrm{O} 2]}\end{array}$ \\
\hline
\end{tabular}


Salt Bridges

\begin{tabular}{|c|c|c|c|c|c|c|c|c|c|c|c|c|}
\hline Index & \multicolumn{2}{|c|}{ Residue } & \multicolumn{2}{|l|}{ AA } & \multicolumn{2}{|c|}{ Distance } & \multicolumn{2}{|c|}{ Protein positive? } & \multicolumn{2}{|c|}{ Ligand Group } & \multicolumn{2}{|c|}{ Ligand Atoms } \\
\hline & $\begin{array}{l}\text { 2a5i_SARS- } \\
\text { CoV-2 }\end{array}$ & $2 \mathrm{a} 5 \mathrm{i}$ & $\begin{array}{l}\text { 2a5i_SARS- } \\
\text { CoV-2 }\end{array}$ & $2 \mathrm{a} 5 \mathrm{i}$ & $\begin{array}{l}\text { 2a5i_SARS- } \\
\text { CoV-2 }\end{array}$ & $2 \mathrm{a} 5 \mathrm{i}$ & $\begin{array}{l}\text { 2a5i_SARS- } \\
\text { CoV-2 }\end{array}$ & $2 \mathrm{a} 5 \mathrm{i}$ & $\begin{array}{l}\text { 2a5i_SARS- } \\
\text { CoV-2 }\end{array}$ & $2 \mathrm{a} 5 \mathrm{i}$ & $\begin{array}{l}\text { 2a5i_SARS- } \\
\text { CoV-2 }\end{array}$ & $2 \mathrm{a} 5 \mathrm{i}$ \\
\hline 1 & $3308 \mathrm{~A}$ & $41 \mathrm{~A}$ & HIS & HIS & 5.10 & 5.08 & $\checkmark$ & $\checkmark$ & Carboxylate & Carboxylate & 2412,2413 & 2481,2480 \\
\hline
\end{tabular}

Water Bridges

\begin{tabular}{|c|c|c|c|c|c|c|c|c|c|c|c|c|c|c|c|c|c|c|c|c|}
\hline Inde & \multicolumn{2}{|c|}{ Residue } & \multicolumn{2}{|c|}{ AA } & \multicolumn{2}{|c|}{ Dist. A-W } & \multicolumn{2}{|c|}{ Dist. D-W } & \multicolumn{2}{|c|}{ Donor Angle } & \multicolumn{2}{|c|}{ Water Angle } & \multicolumn{2}{|c|}{ Protein donor? } & \multicolumn{2}{|c|}{ Donor Atom } & \multicolumn{2}{|c|}{ Acceptor Atom } & \multicolumn{2}{|c|}{ Water Atom } \\
\hline & $\begin{array}{l}2 \mathrm{a} 5 \mathrm{i} \\
\text { _SARS } \\
-\mathrm{CoV}-2\end{array}$ & $\begin{array}{l}2 \mathrm{a} 5 \\
\mathrm{i}\end{array}$ & $\begin{array}{l}2 \mathrm{a} 5 \mathrm{i} \\
\text { _SARS } \\
\text {-CoV-2 }\end{array}$ & $\begin{array}{l}2 \mathrm{a} 5 \\
\mathrm{i}\end{array}$ & $\begin{array}{l}2 \mathrm{a} 5 \mathrm{i} \\
\text { SARS } \\
-\mathrm{C} \text {-CoV-2 }\end{array}$ & $\begin{array}{l}2 \mathrm{a} 5 \\
\mathrm{i}\end{array}$ & $\begin{array}{l}2 \mathrm{a} 5 \mathrm{i} \\
\text { _SARS } \\
-\mathrm{C} \text {-CoV-2 }\end{array}$ & $\begin{array}{l}2 \mathrm{a} 5 \\
\mathrm{i}\end{array}$ & $\begin{array}{l}2 \mathrm{a} 5 \mathrm{i} \\
\text { _SARS } \\
-\mathrm{CoV}-2\end{array}$ & $\begin{array}{l}2 \mathrm{a} 5 \\
\mathrm{i}\end{array}$ & $\begin{array}{l}2 \mathrm{a} 5 \mathrm{i} \\
\text { _SARS } \\
\text {-CoV-2 }\end{array}$ & $\begin{array}{l}2 \mathrm{a} 5 \\
\mathrm{i}\end{array}$ & $\begin{array}{l}2 \mathrm{a} 5 \mathrm{i} \\
\text { _SARS } \\
-\mathrm{C} \text {-CoV-2 }\end{array}$ & $\begin{array}{l}2 \mathrm{a} 5 \\
\mathrm{i}\end{array}$ & $\begin{array}{l}2 \mathrm{a} 5 \mathrm{i} \\
\text { SARS } \\
-\mathrm{SAOV}-2\end{array}$ & $\begin{array}{l}2 \mathrm{a} 5 \\
\mathrm{i}\end{array}$ & $\begin{array}{l}2 \mathrm{a} 5 \mathrm{i} \\
\text { SARS } \\
-\mathrm{C} \text {-CoV-2 }\end{array}$ & $\begin{array}{l}2 \mathrm{a} 5 \\
\mathrm{i}\end{array}$ & $\begin{array}{l}2 \mathrm{a} 5 \mathrm{i} \\
\text { _SARS } \\
-\mathrm{CoV}-2\end{array}$ & $\begin{array}{l}2 \mathrm{a} 5 \\
\mathrm{i}\end{array}$ \\
\hline 1 & $189 \mathrm{~A}$ & - & GLN & - & 4.07 & - & 3.93 & - & 115.60 & - & 91.13 & - & $\curvearrowright$ & - & $\begin{array}{l}1510 \\
\text { [Nam] }\end{array}$ & - & $\begin{array}{l}2456 \\
{[\mathrm{Nam}]}\end{array}$ & - & 2543 & - \\
\hline
\end{tabular}


Supplementary Table 3 Comparison of binding properties of Novel Coronavirus protein from region 1568-1882 (3e9s_SARS-CoV-2) and 3e9s template to ligand Small molecule Noncovalent Lead Inhibitor

Hydrophobic Interactions

\begin{tabular}{|c|c|c|c|c|c|c|c|c|c|c|}
\hline Index & \multicolumn{2}{|l|}{ Residue } & \multicolumn{2}{|l|}{ AA } & \multicolumn{2}{|l|}{ Distance } & \multicolumn{2}{|l|}{ Ligand Atom } & \multicolumn{2}{|l|}{ Protein Atom } \\
\hline & $3 \mathrm{e} 9 \mathrm{~s}$ SARS-CoV-2 & $3 e 9 s$ & 3e9s_SARS-CoV-2 & $3 \mathrm{e} 9 \mathrm{~s}$ & 3e9s_SARS-CoV-2 & $3 \mathrm{e} 9 \mathrm{~s}$ & 3e9s SARS-CoV-2 & $3 \mathrm{e} 9 \mathrm{~s}$ & $3 \mathrm{e} 9 \mathrm{~s}$ SARS-CoV-2 & $3 \mathrm{e} 9 \mathrm{~s}$ \\
\hline 1 & $1731 \mathrm{~A}$ & $165 \mathrm{~A}$ & ASP & ASP & 3.82 & 3.83 & 2502 & 2504 & 1308 & 1320 \\
\hline 2 & $1814 \mathrm{~A}$ & $248 \mathrm{~A}$ & PRO & PRO & 3.79 & 3.80 & 2501 & 2503 & 1955 & 1952 \\
\hline 3 & $1815 \mathrm{~A}$ & $249 \mathrm{~A}$ & PRO & PRO & 3.52 & 3.75 & 2503 & 2505 & 1963 & 1960 \\
\hline 4 & $1831 \mathrm{~A}$ & $265 \mathrm{~A}$ & TYR & TYR & 3.50 & 3.57 & 2503 & 2505 & 2090 & 2089 \\
\hline 5 & $1831 \mathrm{~A}$ & $265 \mathrm{~A}$ & TYR & TYR & 3.63 & 3.67 & 2504 & 2506 & 2091 & 2090 \\
\hline 6 & $1835 \mathrm{~A}$ & - & TYR & - & 3.62 & - & 2502 & - & 2121 & - \\
\hline 7 & 1836A & $270 \mathrm{~A}$ & GLN & GLN & 3.60 & 3.59 & 2502 & 2504 & 2130 & 2129 \\
\hline 8 & 1836A & $270 \mathrm{~A}$ & GLN & GLN & 3.58 & 3.62 & 2507 & 2509 & 2130 & 2129 \\
\hline 9 & $1868 \mathrm{~A}$ & $302 \mathrm{~A}$ & THR & THR & 3.37 & 3.54 & 2514 & 2516 & 2381 & 2385 \\
\hline
\end{tabular}

\section{Hydrogen Bonds}

\begin{tabular}{|c|c|c|c|c|c|c|c|c|c|}
\hline Index & Residue & AA & Distance H-A & Distance D-A & Donor Angle & Protein donor? & Sidechain & Donor Atom & Acceptor Atom \\
\hline 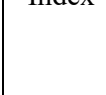 & Mesicute & & Discante & 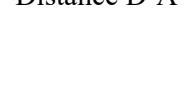 & 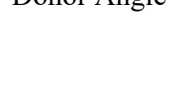 & 1 & 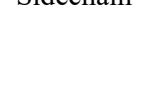 & 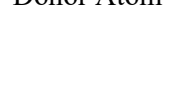 & 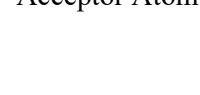 \\
\hline
\end{tabular}




\begin{tabular}{|c|c|c|c|c|c|c|c|c|c|c|c|c|c|c|c|c|c|c|}
\hline & $\begin{array}{c}3 \mathrm{e} 9 \mathrm{~s} \\
\mathrm{SARS} \\
-\mathrm{CoV}- \\
2\end{array}$ & $3 \mathrm{e} 9 \mathrm{~s}$ & $\begin{array}{c}3 \mathrm{e} 9 \mathrm{~s} \\
\text { SARS } \\
-\mathrm{CoV}- \\
2\end{array}$ & $3 \mathrm{e} 9 \mathrm{~s}$ & $\begin{array}{c}3 \mathrm{e} 9 \mathrm{~s} \\
\text { SARS } \\
-\mathrm{CoV}- \\
2\end{array}$ & $3 \mathrm{e} 9 \mathrm{~s}$ & $\begin{array}{c}3 \mathrm{e} 9 \mathrm{~s} \\
\text { SARS } \\
-\mathrm{CoV}- \\
2\end{array}$ & $3 \mathrm{e} 9 \mathrm{~s}$ & $\begin{array}{c}3 \mathrm{e} 9 \mathrm{~s} \\
\mathrm{SARS} \\
-\mathrm{CoV}- \\
2\end{array}$ & $3 \mathrm{e} 9 \mathrm{~s}$ & $\begin{array}{c}3 \mathrm{e} 9 \mathrm{~s} \\
\mathrm{SARS} \\
-\mathrm{CoV}- \\
2\end{array}$ & $3 \mathrm{e} 9 \mathrm{~s}$ & $\begin{array}{l}3 \mathrm{e} 9 \mathrm{~s} \\
\text { SARS- } \\
\text { CoV-2 }\end{array}$ & $3 \mathrm{e} 9 \mathrm{~s}$ & $\begin{array}{c}3 \mathrm{e} 9 \mathrm{~s} \\
\mathrm{SARS} \\
-\mathrm{CoV}- \\
2\end{array}$ & $3 \mathrm{e} 9 \mathrm{~s}$ & $\begin{array}{c}3 \mathrm{e} 9 \mathrm{~s} \\
\mathrm{SARS} \\
-\mathrm{CoV}- \\
2\end{array}$ & $3 \mathrm{e} 9 \mathrm{~s}$ \\
\hline 1 & $1731 \mathrm{~A}$ & $165 \mathrm{~A}$ & ASP & ASP & 2.12 & 2.19 & 2.98 & 3.03 & 151.51 & $\begin{array}{l}149.7 \\
1\end{array}$ & $\nu$ & $\checkmark$ & $\checkmark$ & $v$ & $\begin{array}{l}1311 \\
{[\mathrm{O} 3]}\end{array}$ & $\begin{array}{l}1323 \\
{[\mathrm{O} 3]}\end{array}$ & $\begin{array}{l}2512 \\
{[\mathrm{Nam}]}\end{array}$ & $\begin{array}{l}2514 \\
{[\mathrm{Nam}]}\end{array}$ \\
\hline 2 & $1731 \mathrm{~A}$ & $165 \mathrm{~A}$ & ASP & ASP & 2.00 & 2.05 & 2.98 & 3.03 & 173.11 & $\begin{array}{l}175.8 \\
0\end{array}$ & $x$ & $x$ & $v$ & $v$ & $\begin{array}{l}2512 \\
{[\mathrm{Nam}]}\end{array}$ & $\begin{array}{l}2514 \\
\text { [Nam } \\
\text { ] }\end{array}$ & $\begin{array}{l}1311 \\
\text { [O3] }\end{array}$ & $\begin{array}{l}1323 \\
{[\mathrm{O} 3]}\end{array}$ \\
\hline 3 & $1835 \mathrm{~A}$ & $269 \mathrm{~A}$ & TYR & TYR & 2.78 & 2.81 & 3.61 & 3.64 & 143.08 & $\begin{array}{l}142.3 \\
3\end{array}$ & x & $x$ & $v$ & $v$ & $\begin{array}{l}2511 \\
{[\mathrm{Npl}]}\end{array}$ & $\begin{array}{l}2513 \\
{[\mathrm{Npl}]}\end{array}$ & $\begin{array}{l}2124 \\
\text { [O3] }\end{array}$ & $\begin{array}{l}2123 \\
\text { [O3] }\end{array}$ \\
\hline 4 & $1836 \mathrm{~A}$ & $270 \mathrm{~A}$ & GLN & $\overline{\text { GLN }}$ & 1.87 & 1.77 & 2.83 & 2.75 & 164.21 & $\begin{array}{l}174.6 \\
5\end{array}$ & $\nu$ & $v$ & $x$ & $x$ & $\begin{array}{l}2125 \\
{[\mathrm{Nam}]}\end{array}$ & $\begin{array}{l}2124 \\
\text { [Nam } \\
\text { ] }\end{array}$ & $\begin{array}{l}2509 \\
{[\mathrm{O} 2]}\end{array}$ & $\begin{array}{l}2511 \\
{[\mathrm{O} 2]}\end{array}$ \\
\hline
\end{tabular}

$\pi$-Stacking

\begin{tabular}{|c|c|c|c|c|c|c|c|c|c|c|c|c|c|c|}
\hline Index & \multicolumn{2}{|c|}{ Residue } & \multicolumn{2}{|l|}{$\mathrm{AA}$} & \multicolumn{2}{|c|}{ Distance } & \multicolumn{2}{|l|}{ Angle } & \multicolumn{2}{|l|}{ Offset } & \multicolumn{2}{|l|}{ Type } & \multicolumn{2}{|c|}{ Ligand Atoms } \\
\hline & $\begin{array}{c}\text { 3e9s_SARS- } \\
\text { CoV-2 }\end{array}$ & $3 \mathrm{e} 9 \mathrm{~s}$ & $\begin{array}{c}\text { 3e9s_SARS- } \\
\text { CoV-2 }\end{array}$ & $3 \mathrm{e} 9 \mathrm{~s}$ & $\begin{array}{c}\text { 3e9s_SARS- } \\
\text { CoV-2 }\end{array}$ & $3 \mathrm{e} 9 \mathrm{~s}$ & $\begin{array}{c}\text { 3e9s_SARS- } \\
\text { CoV-2 }\end{array}$ & $3 \mathrm{e} 9 \mathrm{~s}$ & $\begin{array}{c}\text { 3e9s_SARS- } \\
\text { CoV-2 }\end{array}$ & $3 \mathrm{e} 9 \mathrm{~s}$ & $\begin{array}{c}\text { 3e9s_SARS- } \\
\text { CoV-2 }\end{array}$ & $3 \mathrm{e} 9 \mathrm{~s}$ & $\begin{array}{l}3 \mathrm{e} 9 \mathrm{~s} \\
\text { SARS- } \\
\text { CoV-2 }\end{array}$ & $3 \mathrm{e} 9 \mathrm{~s}$ \\
\hline 1 & $1835 \mathrm{~A}$ & $269 \mathrm{~A}$ & TYR & TYR & 5.30 & 5.31 & 84.17 & 85.46 & 1.70 & 1.70 & $\mathrm{~T}$ & $\mathrm{~T}$ & $\begin{array}{l}2497, \\
2500, \\
2503, \\
2506, \\
2508, \\
2516\end{array}$ & $\begin{array}{l}2499, \\
2502, \\
2505, \\
2508, \\
2510, \\
2518\end{array}$ \\
\hline
\end{tabular}




\begin{tabular}{|c|c|c|c|c|c|c|c|c|c|c|c|c|c|c|}
\hline 2 & $1835 \mathrm{~A}$ & $269 \mathrm{~A}$ & TYR & TYR & 5.09 & 5.10 & 84.10 & 85.40 & 0.83 & 0.85 & $\mathrm{~T}$ & $\mathrm{~T}$ & $\begin{array}{l}2497, \\
2498, \\
2500, \\
2501, \\
2515, \\
2517\end{array}$ & $\begin{array}{l}2499 \\
2500 \\
2502, \\
2503, \\
2517, \\
2519\end{array}$ \\
\hline 3 & - & $269 \mathrm{~A}$ & - & TYR & - & 5.18 & - & 73.97 & - & 1.96 & - & $\mathrm{T}$ & - & $\begin{array}{l}2498, \\
2501, \\
2504, \\
2507, \\
2509, \\
2512\end{array}$ \\
\hline
\end{tabular}

